\title{
Labor Market Polarization, Job Tasks and Monopsony Power
}

\author{
Ronald Bachmann Gökay Demir Hanna Frings
}

\begin{abstract}
Using a semi-structural approach based on a dynamic monopsony model, we examine to what extent workers performing different job tasks are exposed to different degrees of monopsony power, and whether these differences in monopsony power have changed over the last 30 years. We find that workers performing mostly non-routine cognitive tasks are exposed to a higher degree of monopsony power than workers performing routine or non-routine manual tasks. Job-specific human capital and non-pecuniary job characteristics are the most likely explanations for this result. We find no evidence that labor market polarization has increased monopsony power over time.
\end{abstract}

Ronald Bachmann is head of the research unit "Labor Markets, Education, Population" at RWI Leibniz Institute for Economic Research in Essen, Germany, adjunct professor of labor economics at the Düsseldorf Institute for Competition Economics (DICE) at Heinrich Heine University Düsseldorf, and Research Fellow at IZA (bachmann@rwi-essen.de). Gökay Demir is researcher at RWI and Heinrich Heine University Düsseldorf. Hanna Frings is deputy head of the research unit "Labor Markets, Education, Population" at RWI and Research Affiliate at IZA. The authors are grateful to Daniel Baumgarten, Christian Bredemeier, Arin Dube, Matthias Giesecke, Laszlo Goerke, Boris Hirsch, Jochen Kluve, Alan Manning, John Pencavel, Todd Sørensen, Colin Vance, and to participants at the Princeton Monopsony Conference 2018, the EALE and ESPE 2019 Annual Conferences, the IAB Workshop "Perspectives on (Un-)Employment", the 5th User Conference of the IAB-FDZ, the SEA 2020 conference, and seminars at the Institute for Labor Law and Industrial Relations in the European Union (IAAEU) and at RWI for helpful comments. The Online Appendix to this article can be found at http://jhr.uwpress.org/.

The authors have nothing to disclose. This paper uses confidential data from the Research Data Centre (FDZ) of the German Federal Employment Agency (BA) at the Institute for Employment Research (IAB) (project number fdz1631). The data can be obtained by submitting an application to the Research Data Centre (FDZ). Details on applying for the dataset and possibilities for data processing can be found on the FDZ homepage (https://fdz.iab.delen.aspx). The authors are willing to assist.

JEL Classification: J24; J42; J62 


\section{Introduction}

The labor market effects of technological change through digitalization and the increased use of robots and artificial intelligence have raised major concerns amongst the public, politicians, and academic economists in recent years. Indeed, workers performing jobs with a high degree of routine task intensity (RTI) are most at risk because their jobs are relatively easily substitutable by computers and robots; as a result, routine employment has strongly fallen over the past decades, both in Europe and in the US (Goos, Manning, and Salomons 2009; Autor, Levy, and Murnane 2003; Autor and Dorn 2013). As routine jobs are concentrated in the middle of the wage distribution, this trend has led to job polarization. However, it remains unclear whether - and if so, how - technological change and the ensuing polarization of the labor market have changed the wage-setting power of employers, that is, monopsony power. Furthermore, there is clear evidence that monopsony power matters for wage gaps between worker groups such as men and women or migrants and natives (Hirsch, Schank, and Schnabel 2010; Hirsch and Jahn 2015). Differences in monopsony power between workers performing different job tasks have, in contrast, not been investigated yet. These issues are important because monopsony power is a crucial determinant of wages and therefore of workers' welfare.

In this paper, we therefore investigate the link between labor market polarization, job tasks, and the degree of monopsony power. We do so by answering three research questions. First, are workers who perform different job tasks exposed to different degrees of monopsony power? Second, how did the degree of monopsony power evolve over time for workers performing different job tasks? Third, which factors can explain the differences in monopsony power between workers performing jobs with different job tasks? We thus contribute to the literature on 
monopsony power by providing the first evidence on the relation between the task content of jobs and the market power of employers, both in a cross-sectional setting and over time.

For potential cross-sectional differences of monopsony power between workers performing different job tasks, two sources of monopsony power seem particularly relevant from a theoretical point of view: job-specific human capital and non-pecuniary job characteristics. As discussed in more detail in the next section, job-specific human capital is likely to be more important for highskilled workers working in non-routine cognitive (NRC) jobs; these workers are also likely to have stronger preferences for non-pecuniary factors such as working conditions or job satisfaction.

Furthermore, the differences in monopsony power by job task intensities could have changed over time, especially as job opportunities have declined for workers with highly routine jobs in industrialized countries during the last decades (Cortes 2016; Goos, Manning, and Salomons 2014). A decline in job opportunities, that is, lower labor demand, has been shown in a business-cycle context to increase the degree of monopsonistic competition (Depew and Sørensen 2013; Hirsch, Jahn, and Schnabel 2018; Webber 2020). Given the decline in job opportunities of workers performing highly routine tasks, one could therefore expect higher monopsony power towards theses workers over time.

To empirically answer our three research questions, we use the semi-structural estimation method proposed by Manning (2003) which has frequently been applied in the literature to assess the degree of monopsony power in the labor market. ${ }^{1}$ This estimation method is based on the Burdett and Mortensen (1998) model of the labor market which includes wage posting by firms and on-the-job search by workers who can be employed or unemployed. Workers are searching for higher wages, which implies that their mobility decisions depend on the wage differences between jobs. Firms try to attract workers through their wage offers. The resulting monopsony power of 
firms is captured by the wage elasticity of labor supply to the firm. A low wage elasticity implies that firms can set wages without having to fear strong mobility reactions by workers; therefore, monopsony power is high. Conversely, a high wage elasticity implies low monopsony power. The wage elasticity to the firm is estimated indirectly by estimating its components: On the worker side, the wage elasticities of workers' separation decisions (to employment and to nonemployment) indicate how strongly workers react to wage differences; the share of hires from employment weights these two separation elasticities. On the firm side, the wage elasticity of the share of recruits hired from employment indicates how easy it is for firms to poach workers from other firms.

We apply two approaches to determine the task content each worker performs in his job. First, we follow the international literature on labor market polarization which differentiates between relatively broad task groups that are fixed over time (see for example Goos and Manning 2007; Goos, Manning, and Salomons 2009; Cortes 2016). To facilitate the comparability of our results with this well-established literature, we estimate the wage elasticity separately for task groups, in our case routine, non-routine cognitive (NRC), and non-routine manual (NRM) workers. A disadvantage of this classification of workers via occupations into task groups is that it is rather broad and fixed over the entire observation period. As our main approach, we therefore use a survey data set on job tasks. This allows us to include continuous measures of task intensities as explanatory variables, as Bachmann, Cim, and Green (2019) do for routine task intensity. In contrast to the first approach, we are therefore able to employ time-varying intensity measures for routine, non-routine cognitive, and non-routine manual tasks. These time-varying task intensity measures mitigate potential measurement errors due to changing occupational task contents over 
time. Furthermore, this approach allows us to quantify the importance of job task intensities for differences in monopsony power between workers.

Our analysis is based on two unique data sets from Germany. First, we use administrative data on individual labor-market histories spanning the years 1985-2014. This data set includes several socio-demographic worker characteristics as well as firm characteristics and is particularly well suited to identify labor market transitions, including job-to-job transitions. Second, we use survey data that contains time-varying information on individual job tasks. From this data set, we compute the intensities of routine, non-routine cognitive, and non-routine manual job tasks at the occupational level, which we merge to the administrative data set.

Our analysis is closely related to the recent literature on routine-biased technological change (RBTC) and worker flows. Cortes and Gallipoli (2018), using data from the Current Population Survey (CPS) and the Dictionary of Occupational Titles (DOT), examine the importance of task distance between occupations (as in Gathmann and Schönberg 2010) for the corresponding worker flows in the US. They show that for most occupation pairs, task-specific costs account for up to 15 percent of the costs that arise when individuals move between occupations. Bachmann, Cim, and Green (2019) analyze the link between labor market transitions and job tasks for the German labor market. They find differences in the mobility patterns of workers belonging to different task groups, and that RTI plays an important role for worker mobility.

Our results can be summarized as follows: First, workers with high routine task content in their occupation display a higher wage elasticity of labor supply to the firm than workers with a high non-routine cognitive task content in their occupation. This indicates that workers with high non-routine cognitive task content are subject to higher monopsony power by employers. A decomposition analysis of the components of this wage elasticity shows that this result mainly 
arises because workers with high non-routine cognitive task content are much less likely to separate to employment than routine workers. Second, the differences in monopsony power between workers performing jobs with low RTI and workers performing jobs with high RTI stay relatively constant over time, and we do not find pronounced long-run trends for any worker group. This can be seen as an indication that technological progress and the corresponding polarization of the labor market has not increased monopsony power over time. Third, we provide evidence on explanations for the higher monopsony power towards NRC workers: these workers dispose of more job-specific human capital, and they assign a higher importance to non-pecuniary benefits than workers performing jobs with higher routine or non-routine manual task content. Finally, we find that collective bargaining coverage matters for the overall degree of monopsony power of the labor market, but that collective bargaining coverage cannot explain differences between workers performing jobs with different tasks.

Our paper therefore makes two important contributions to the literature. First, we provide evidence on the link between job tasks and monopsonistic competition, and especially to quantify the importance of job task intensities in this context. Furthermore, we investigate potential reasons for the differences in monopsony power that is faced by workers performing different job tasks. Second, we analyze the degree of monopsonistic competition over a long time period using timevarying measures of job task intensities.

\section{Task Groups, Technological Progress, and Monopsony Power}

Workers' job search and mobility behavior in the labor market, as well as the ensuing monopsony power of firms, can be analyzed using the Burdett and Mortensen (1998) equilibrium search model, 
which is also the theoretical foundation of our empirical approach described in Section III. The model features firms which post wages to fill jobs, and workers who can be employed or unemployed, and who search on the job when employed. ${ }^{2}$ In this model, the wage elasticities of workers' separations to employment and unemployment are two key determinants of monopsony power: ${ }^{3}$ If workers react strongly to wage differences, firms have little discretion in setting wages, and monopsony power is low. By contrast, if workers hardly react to wage differences, firms have high monopsony power. The job mobility of workers depends on the job offer arrival rate, given the wage offer distribution, as well as on factors that can give rise to monopsony power: jobspecific human capital (Webber 2015), preferences for non-pecuniary job characteristics, search frictions, and mobility costs (Manning 2003).

Our first research question is whether workers who perform different job tasks are exposed to different degrees of monopsony power. We therefore discuss for each source of monopsony power if and why we expect this source to have a different effect on monopsony power across task groups. The first source of monopsony power, job-specific human capital, implies that a job change leads to a loss of human capital. The existence of job-specific human capital therefore decreases workers' incentives to switch jobs to improve their wage, that is, it increases monopsony power of employers. Importantly for our purpose, one reason why human capital is job-specific, and therefore gets lost with a job change, is that job tasks often change when a worker changes job (Gathmann and Schönberg 2010).

There are two reasons why the job-specificity of human capital, and thereby the degree of monopsonistic competition stemming from this source, is highest for workers performing NRC tasks. First, the production of output generally requires the combination of tasks into task bundles, and more highly skilled workers can perform more complex tasks. For example, in the labor market 
model of Acemoglu and Autor (2011) with high-, medium-, and low-skilled workers, each task can be performed by every skill type, but the comparative advantage of skill types differs across tasks. Thus, more complex tasks can be better performed by high-skilled workers than medium-skilled workers, while intermediate tasks can be better performed by medium-skilled workers than lowskilled workers. Furthermore, it costs strictly less to perform simpler tasks with low-skilled rather than medium-skilled or high-skilled workers. As a result, more complex tasks are performed by high-skilled workers, less complex tasks by low-skilled workers (Acemoglu and Autor 2011). As high-skilled workers perform more complex tasks, they are more likely to lose human capital when they change job, which increases the monopsony power of firms.

Second, complex tasks often require collaboration. This has been shown in the model of Booth and Zoega (2008), where the range of tasks firms can perform is determined by the collective ability of its entire workforce. Therefore, worker heterogeneity translates into firm heterogeneity when collective abilities within firms are not identical. In this model, only firms characterized by workforces of higher ability can perform complex tasks, and complex tasks can be performed in a smaller number of firms than simpler tasks. As a result, high-skilled workers are only able to perform the most complex tasks in relatively few firms with a very specific workforce, and therefore these workers only have few outside options. Firms performing complex tasks therefore have high monopsony power towards their workers, particularly the high-skilled ones who predominantly perform NRC tasks.

The second source of monopsony power consists of preferences for non-pecuniary job characteristics such as working conditions or job satisfaction. The importance of non-pecuniary job characteristics has been stressed in the compensating wage differentials literature (Rosen 1986). More recently, it has been shown that workers in the US are willing to give up part of their 
compensation to avoid unfavorable working conditions (Mas and Pallais 2017), and that high-wage workers and college-educated workers have uniformly better job characteristics (Maestas et al. 2018). Non-pecuniary job characteristics also play an important role in explaining job mobility. Sullivan and To (2014) show that there are substantial gains to workers from job search based on non-pecuniary factors and that workers have a tendency to sort into jobs with better non-pecuniary job characteristics that they are willing to pay for. Sorkin (2018) shows that workers systematically sort into lower-paying firms which provide better non-pecuniary job characteristics. Finally, Lamadon, Mogstad, and Setzler (2019) show that worker preferences over non-pecuniary job characteristics lead to imperfect competition in the US labor market. Given these results from the literature, we expect non-pecuniary job characteristics to be most important for workers performing NRC tasks, implying a higher degree of monopsony power faced by these workers.

For the two remaining sources of monopsony power, search frictions through information imperfections and mobility costs leading to limited regional mobility, the literature does not provide strong indications why these should differ between task groups. In our empirical analysis of mechanisms leading to differences in monopsony power between task groups in Section V.C, we therefore focus on the first two mechanisms: job-specific human capital and non-pecuniary job characteristics.

Our second research question is how the degree of monopsony power evolved over time for workers performing different job tasks. It seems likely that the differences in monopsony power between task groups have changed over time because the general labor market situation of workers belonging to different task groups has evolved very differently in recent decades. There is ample evidence for the US and many European countries that routine work has strongly declined (see for example Autor and Dorn 2013; Goos, Manning, and Salomons 2014), and that this has had adverse 
effects on routine workers' long-term employment probabilities (see Bachmann, Cim, and Green 2019 for Germany and Cortes 2016 for the US) and wages (Cortes 2016).

These general developments are likely to have affected the evolution of monopsony power in the labor market for workers performing routine tasks. As shown by Depew and Sørensen (2013) and Hirsch, Jahn, and Schnabel (2018) in a business-cycle context, the degree of monopsonistic competition in the labor market increases at times in which labor demand is relatively low. The most important explanation for this is that workers' job separations are less wage-driven when unemployment is high. Intuitively, a higher unemployment rate leads to worse outside opportunities for workers. Therefore, job security becomes more important for workers which increases search frictions and thus monopsony power (Hirsch, Jahn, and Schnabel 2018).

Extending this argument to a long-run analysis, we expect that the labor supply elasticity to the firm has decreased for routine workers. This is so because labor market polarization has led to a reduction of jobs with predominantly routine task content, which means that outside options decreased for workers specialized in performing routine tasks. Within the Burdett and Mortensen (1998) model, this demand-side effect would mainly feature as a reduction in the job offer arrival rate. Workers performing routine tasks will therefore be limited in their ability to separate from a job to find a better-paying one.

It is important to point out that this demand-side effect may in turn be amplified and hence lead to changes in monopsony power. Similarly to the business-cycle studies cited above, an important reason for this is that routine workers become more risk averse in their mobility decision given limited outside options. Consequently, workers will prefer job stability over a wage raise. This would reduce the wage elasticity of job separations, thus amplifying the initial demand shock. 
By contrast, we expect the wage elasticity of labor supply to the firm for workers performing NRC tasks to increase over time, because labor market polarization has led to an increase of outside options for this task group. This increase could for example be caused by the emergence of new tasks that can be performed best by high-skilled (NRC) workers as in the model by Acemoglu and Restrepo (2018). Again, one should distinguish between a pure demand-side effect and an amplification effect. In the case of NRC workers, this amplification effect would further increase the wage elasticity of job separations, even for a constant job offer arrival rate, because NRC workers have increasingly good labor-market prospects and therefore become less risk averse in their mobility decisions.

Finally, there exists another long-run trend that could have affected the evolution of monopsony power in the labor market: the rise of superstar firms. As Autor et al. (2020) point out, technological change and globalization benefit the most productive firms in each industry. This leads to product market concentration as industries become increasingly dominated by superstar firms with high profits and a low share of labor in firm value-added and sales. This increased product market concentration is likely to be accompanied by stronger labor market concentration and thus to lead to monopsony power in the labor market, as shown for the US by Azar, Marinescu, and Steinbaum (2020). Therefore, this long-run trend can be viewed as a change in the composition of firms towards more firms with high monopsony power, which raises overall monopsony power in the labor market. 


\section{Empirical Methodology}

In the following, we briefly summarize the method to empirically estimate the wage elasticity of labor supply to the firm, the measure of monopsony power pioneered by Manning (2003). This method is based on the Burdett and Mortensen (1998) model introduced in Section II, where workers leave the firm at a rate $s\left(w_{t}\right)$ that depends negatively on the wage paid. The number of new recruits $R\left(w_{t}\right)$ depends positively on the wage paid. The law of motion for labor supply to the firm can therefore be expressed as

$$
L_{t}=R^{e}\left(w_{t}\right)+R^{n}\left(w_{t}\right)+\left[1-s^{e}\left(w_{t}\right)-s^{n}\left(w_{t}\right)\right] L_{t-1}
$$

with firms paying wage $w_{t}$ at time $t$. The exponents $e$ and $n$ indicate the destination states (for separations) or states of origin (for recruitments) corresponding to employment and nonemployment, respectively. Considering the steady state in which total separations must equal recruits and $L_{t} \equiv L$ and $w_{t} \equiv w$, we have

$$
L(w)=\frac{R^{e}(w)+R^{n}(w)}{s^{e}(w)+s^{n}(w)}
$$

which results in a positive long-run relationship between employment and wages. Equation 2 implies that the long-term elasticity of labor supply to the individual firm $\epsilon_{L w}$ is the difference of a weighted average between the wage elasticities of recruitment from employment $\left(\epsilon_{R w}{ }\right)$ and nonemployment $\left(\epsilon_{R w}^{n}\right)$, and the wage elasticities of the separation rates to employment $\left(\epsilon_{s w}^{e}\right)$ and nonemployment $\left(\epsilon_{s w}^{n}\right)$, that is,

$$
\epsilon_{L w}=\theta_{R} \epsilon_{R w}^{\mathrm{e}}+\left(1-\theta_{R}\right) \epsilon_{R w}^{n}-\theta_{s} \epsilon_{s w}^{e}-\left(1-\theta_{s}\right) \epsilon_{s w}^{n}
$$

where the weights are given by $\theta_{R}$, the share of recruits hired from employment, and $\theta_{s}$, the share of separations to employment.

Estimating the separation rate elasticities using data on job durations is relatively straightforward but estimating the recruitment elasticities requires information that is typically not 
available in data sets. Specifically, we do not have information on the firms' applicants and the wages offered to them. A solution is to impose additional structure on the model by assuming a steady state which implies that $\theta \equiv \theta_{R}=\theta_{s}$ holds. Imposing this on Equation 3 gives the following relation $^{4}$

$$
\epsilon_{L w}=-(1+\theta) \epsilon_{s w}^{e}-(1-\theta) \epsilon_{s w}^{n}-\epsilon_{\theta \mathrm{w}},
$$

where $\epsilon_{\theta w}$ is the wage elasticity of the share of recruits hired from employment and $\theta$ is the overall share of hires from employment. The four components of the wage elasticity of labor supply to the firm are thus the wage elasticity of the separation rate to employment, the wage elasticity of the separation rate to nonemployment, the wage elasticity of the share of recruits from employment, and the share of recruits from employment. One can therefore estimate these four components to arrive at the wage elasticity of labor supply to the firm. This estimation approach is widely used in the literature (Hirsch, Schank, and Schnabel 2010; Booth and Katic 2011; Hirsch, Jahn, and Schnabel 2018; Hirsch et al. 2020; Webber 2020).

Intuitively, lower wage elasticities of the two separation rates mean that workers react less strongly to wage differences by moving to a new job or to non-employment. This implies that firms have more discretion in setting their wage in this case. Therefore, lower separation rate elasticities lead to a lower labor supply elasticity to the firm, that is, higher monopsony power, in Equation 4. The two separation rate elasticities are weighted by $\theta$, the share of hires from employment, to capture the relative contribution of these two rates to the overall wage elasticity of labor supply. ${ }^{5}$ By contrast, the wage elasticity of the share of hires from employment takes into account the hiring function of the firm. If this elasticity is high, firms find it relatively easy to poach workers from other firms. In this sense, market power of firms is high if this elasticity is high. Therefore, a high 
wage elasticity of the share of hires in employment in Equation 4 reduces the wage elasticity of labor supply to the firm, that is, it increases monopsony power.

Although this estimation approach is widespread, it has recently been criticized for using all variation in wages for the identification of the separation rate elasticities in specific and the labor supply elasticity to the firm in general (Bassier, Dube, and Naidu 2020). We expect workers to react to the firm-specific and the match-specific components of pay in their decision to separate, but not so much to the worker-specific component or any idiosyncratic shock. Keeping all variation in wages instead of focusing on components that are influenced by firm-level wage policies adds noise to the data, and therefore leads to an attenuation bias. Unfortunately, the data used in this study do not allow us to isolate the firm-specific component of pay. We therefore recognize that the estimated elasticities constitute a lower bound, and that the true degree of monopsonistic competition is probably lower than suggested by our estimates. However, this limitation is unlikely to apply to our main research questions dealing with differences in monopsonistic competition over time and between task groups. Therefore, we focus on interpreting the differences between task groups and their evolution over time, rather than the absolute level of monopsony power.

To estimate the components of Equation 4, we proceed as follows. For the separation rate elasticities to employment and non-employment, we model the instantaneous separation rate of employment spell $i$ at duration time $t$ as a Cox proportional hazard model:

$$
s_{i}^{\rho}\left(t, x_{i}^{\rho}(t)\right)=h_{0}(t) \exp \left(x_{i}^{\rho}(\mathrm{t})^{\prime} \beta^{\rho}\right),
$$

where $\rho=e, n$ indicates a separation to employment or non-employment respectively, $h_{0}(t)$ is a baseline hazard with no assumptions on its shape, $x_{i}^{\rho}(t)$ is a vector of time-varying covariates with $\beta^{\rho}$ as a corresponding vector of coefficients. ${ }^{6} x^{\rho}{ }_{i}(t)$ includes log wage as our key independent variable. The corresponding coefficient $\beta^{\rho}$ can directly be interpreted as the wage elasticity of 
separations to employment or non-employment, respectively. Furthermore, we include the following covariates to control for individual- and plant-level as well as economy-wide factors which may affect labor supply to the firm: dummy variables for age and education groups, immigrant status, occupation fields (54 fields, following Tiemann et al. 2008), economic sector (15 sectors, following Eberle et al. 2011), worker composition of the firm (shares of low-skilled, highskilled, female, part-time and immigrant workers in the plant's workforce), plant size (four dummies), the average age of its workforce, as well as year and federal state fixed effects and the unemployment rate by year and federal state.

Estimating Cox proportional hazard models, which place no restrictions on the baseline hazard, forces us to control for job tenure. There are arguments for and against the inclusion of job tenure. On the one hand, Manning $(2003,103)$ argues that including tenure reduces the estimated wage elasticity as high-tenure workers are less likely to leave the firm and are more likely to have high wages. Thus, tenure is itself partly determined by wages, and including it would take away variation from wages and therefore bias the estimated wage elasticity. On the other hand, considering the existence of seniority wage scales, Manning (2003) also argues that the exclusion of job tenure would lead to a spurious relationship between wages and separations. The empirical literature on seniority wage schedules in the German labor market suggests that controlling for tenure is appropriate in our application (see for example Zwick 2011; Zwick 2012). ${ }^{7}$

To arrive at an estimate of the wage elasticity of the share of recruits hired from employment, $\epsilon_{\theta w}$, we model the probability that a worker is hired from employment (as opposed to non-employment) using a logit model:

$$
\operatorname{Pr}\left[\mathrm{y}_{\mathrm{i}}=1 \mid x_{i}\right]=\Lambda\left(x_{i}^{\prime} \beta\right)
$$


where the dependent variable is a dummy, which takes the value 1 if it is a recruit from employment and 0 if the recruit comes from non-employment. $\Lambda$ denotes the cumulative distribution function of the standard logistic distribution. Again, our key independent variable in this equation is log wages. The coefficient of log wages in this model gives the wage elasticity of the share of recruits hired from employment $\epsilon_{\theta w}$ divided by $1-\theta$. Multiplying the coefficient by $1-\theta$ yields the estimate of $\epsilon_{\theta w}$ in Equation 4. To obtain the weights used in Equation 4, we calculate the share of hires coming from employment $\theta$ from the data.

To analyze differences in the wage elasticity of labor supply to the firm between workers performing different job tasks, we proceed in two ways. First, we estimate the respective wage elasticities separately by task group. We follow Cortes (2016) and distinguish three different task categories: (1) Routine: administrative support, operatives, maintenance and repair occupations, production and transportation occupations (among others); (2) Non-Routine Cognitive (NRC): professional, technical management, business and financial occupations; (3) Non-Routine Manual (NRM): service workers. These task groups are rather broad and fixed over time, but the classification allows a direct comparison with the US literature using this type of classification. Second, we use a time-varying measure of task intensities (TI), which we explain in detail in Section IV.B. Here, we include the interaction of the log wage and $T I_{i}(t)$ to estimate the separation rate elasticities in Equation 5. The respective separation rate elasticity is given by $\epsilon^{\rho}{ }_{s w}=\beta^{\rho}{ }_{w}+\beta^{\rho} T I \times w$ $\times T I_{i}(t)$. Similarly, the wage elasticity of the share of recruits hired from employment, $\epsilon_{\theta w}$, is given by $\beta_{w}+\beta_{T I \times w} \times T I_{i}(t)$ divided by $1-\theta$. As this second approach allows us to exactly quantify the link between TI and monopsony power, and because it allows us to control for changes in TI by occupation over time, this is our preferred approach in the empirical analyses in Section V. 


\section{Data}

\section{A. The Sample of Integrated Labor Market Biographies (SIAB) 1975-2014}

This study uses the weakly anonymized Sample of Integrated Labor Market Biographies (SIAB) for the years $1975-2014 .{ }^{8}$ We combine this data with the Establishment History Panel (BHP), also provided by the Research Data Centre of the BA at the IAB. A detailed description of the Sample of Integrated Labor Market Biographies is provided in Antoni, Ganzer, and vom Berge (2016).

The SIAB is a representative 2 percent random sample of the population of the Integrated Employment Biographies (IEB). The IEB includes the universe of individuals with either employment subject to social security, marginal part-time employment (mini-job), registered unemployment benefits, job-seeker status at the Federal Employment Agency, participation in active labor market policy measures or other training measures. The information on the corresponding labor market spells is exact to the day.

The most important data source of the IEB for this paper is the Employee History $(\mathrm{BeH})$. The $\mathrm{BeH}$ is based on the integrated notification procedure for health, pension, and unemployment insurances. Employers have the legal obligation to notify the responsible social security agencies about all of their employees covered by social security at the beginning and at the end of an employment spell, and to update the information at least once a year. Misreporting is a legal offense (for more information on the notification procedure see Bender et al. 1996). Civil servants and selfemployed individuals or spells are not recorded in the $\mathrm{BeH}$, as it only covers employees subject to social security. To identify spells of registered unemployment, we use the Benefit Recipient History (LeH) and the Unemployment Benefit 2 Recipient History (LHG). The data provides us with personal information such as age, gender, nationality, and place of residence, as well as job information such as the daily wage and the occupation. The information on the daily wage is 
censored at the yearly varying social security contribution ceiling. We explain in Section IV.C how we deal with this issue.

Using the establishment identifier that is included in the data, we can link the individuallevel data with the Establishment History Panel (BHP). The BHP data consists of BeH data which is aggregated at the establishment-year level on 30 June of a year. The BHP provides information on the industry of the establishment and other establishment characteristics such as worker group shares with respect to skill, gender, part-time employment, and nationality, as well as the establishment size and the average age of its workforce. Furthermore, it is possible to identify plant closures with the BHP data (see Hethey and Schmieder 2013).

\section{B. BIBB/IAB and BIBB/BAuA Employment Surveys}

To compute task intensities for occupations, we use the BIBB/IAB and BIBB/BAuA Employment Surveys (herein BIBB data) that provide a representative sample of German workers (BIBB 2021). ${ }^{9}$ The BIBB data consists of repeated cross-sections on approximately 20,000 to 30,000 employees in Germany for each survey wave that we use in this paper (1985-6, 1991-2, 1998-9, 2006, and 2012). The BIBB data are representative of the core labor force in Germany, that is, for persons who are at least 15 years old and work at least 10 hours per week. The dataset contains questions about the workplace concerning, for example, job tasks, working conditions, satisfaction with current job, and other non-pecuniary job characteristics.

Among others, Antonczyk, Fitzenberger, and Leuschner (2009), and Baumgarten (2015) use these data to generate measures of relative task intensities at the occupational level. We follow the approach of Antonczyk, Fitzenberger, and Leuschner (2009) and categorize the activities employees perform at the workplace into routine (R), non-routine manual (NRM) and non-routine 
cognitive (NRC). This allows us to compute task intensities at the individual level. We aggregate these individual task intensities for 54 occupational categories following Tiemann et al. (2008), and for each occupation-time period combination provide a R, NRM, and NRC share that sums to 100 percent. ${ }^{10}$ The ensuing task intensity measure (TI) at the individual level $i$ can be expressed as

$$
\text { Task }_{i j t}=\frac{\text { number of activities in category } \mathrm{j} \text { performed by in cross section } \mathrm{t}}{\text { total number of activities performed by i over all categories at time } \mathrm{t}},
$$

where $t=1985-6,1991-2,1998-9,2006$, and 2012 and $j$ indicates routine (R), non-routine manual (NRM), and non-routine cognitive (NRC) tasks, respectively. Taking averages over individuals task intensities by occupational categories provides a continuous measure of routine task intensity (RTI), non-routine manual task intensity (NRMTI), and non-routine cognitive task intensity (NRCTI) over time for a given occupational group. We merge the TI measures to the worker-level SIAB data based on occupation and year combinations.

A key advantage of BIBB is that the survey is conducted at regular six- to seven-year intervals throughout our period of analysis. This allows us to have time-varying task intensities by occupational groups. Doing so allows us to fully exploit the BIBB data to update occupation task intensities over time. This has the advantage that our analysis considers task intensities which are regularly updated and therefore reflect the actual task composition at the time of observation. Thus, computing task intensities with the usage of additional data sources is in contrast to the more parsimonious approach, which assigns workers to routine, non-routine manual, and non-routine cognitive categories at one point in time based on groups of standardized occupational codes (see for example Goos and Manning 2007; Goos, Manning, and Salomons 2009; Cortes 2016). A cost of relying on the time-varying task measures computed from the BIBB data consists in discontinuities in these measures from one survey wave to the next. However, as shown by Bachmann, Cim, and Green (2019), these discontinuities are not large. 


\section{Sample Construction}

The SIAB provides information on workers' employment biographies from 1975 onwards. However, for our analysis, it is only possible to use the data set from 1985 because the wage variable does not include bonus payments before 1985 but does so afterwards. As this results in a strong break in measured wages from 1984-5, we restrict our observation period to 1985-2014. As our observation period includes the preunification period, we focus on West Germany only. Including observations for East German workers from 1992 onwards and therefore restricting our analysis to the post-unification period would considerably reduce our period of observation and thus the long time period needed to properly answer our research questions.

The SIAB data includes the daily wage of every employment spell, but no information on working hours. We therefore focus on full-time workers, as this ensures comparability between daily wage rates. Wages are top-coded at the social security contribution limit. To avoid possible biases in the estimated wage elasticity of labor supply, we exclude all job spells with wages that are at this limit at least once during the observation period. ${ }^{11}$ Further, we convert gross daily wages into real daily wages by using the consumer price index of the Federal Statistical Office.

In our empirical analysis, we focus on the core labor force in dependent employment and therefore exclude apprentices, trainees, homeworkers, and individuals older than 55. We further restrict our analysis to male workers to avoid selectivity issues regarding female labor force participation. Information on workers' education is provided by employers and is therefore inconsistent or missing for some workers. To correct for the inconsistent education information, we impute the missing information on workers' education by using the procedure proposed by Fitzenberger, Osikominu, and Völter (2006). Furthermore, we exclude plants during their closing year, thus mitigating biases resulting from involuntary, demand-side driven separations from a 
job. ${ }^{12}$ Specifically, excluding plants in their closing year helps to mitigate the possible spurious relationship between wages and separations that is not driven by workers' labor supply behavior.

Following the theoretical model based on Manning (2003), we distinguish between two labor market states: employment and non-employment. However, the reports and notifications of establishments and individuals are not always exactly consistent with the actual change of labor market state. For example, workers might report to the unemployment office only a few days after they are laid off. To deal with these potential measurement errors, we define our main dependent variables in the following way:

(i) Separation to employment/ job-to-job transitions: If the time gap between two employment spells at different establishments (that is, an establishment with a different establishment identifier) does not exceed 30 days.

(ii) Separation to registered unemployment or non-employment: If the time gap between two employment spells at different establishments exceeds 30 days, we define this time gap as a non-employment spell. A separation to non-employment is also defined as a job spell ending in registered unemployment or no spell in the data at all. Further, we take care of recalls in the following way: Recalls are defined as one single employment spell if the time gap between two employment notifications at the same firm does not exceed 120 days. If the time gap between two employment notifications at the same firm is equal to or larger than 120 days, we define this gap as an additional non-employment spell. Treating recalls as continuous employment spells ensures that seasonal effects that differ between industries and task groups and may affect wages and transitions into/from non-employment simultaneously do not distort the results.

(iii) Recruitment from employment relative to non-employment: Similar to (i) and (ii), we define a recruitment from employment if the time gap between two employment spells at 
different establishments (that is, an establishment with a different establishment identifier) does not exceed 30 days. A recruitment from non-employment is defined if the time gap between two employment spells at different establishments exceeds 30 days, the individual is hired from registered unemployment, the time gap between two employment notifications at the same firm is equal to or larger than 120 days, or the individual has no spell in the data (prior to recruitment) at all.

Table 1 gives an overview on our final sample which consists of 5,641,241 employment spells from 465,131 workers with 444,864 separations to employment and 742,690 separations to non-employment. The descriptive evidence is in line with the expectations and shows that NRM workers are in the lower, routine workers in the middle and NRC workers in the higher end of the wage and skill distribution (see for example Acemoglu and Autor 2011; Cortes 2016). Our task intensity measures are in line with the task group classification of Cortes (2016). Specifically, the means of the task intensity measures by task groups show that RTI is highest for routine workers, NRMTI is highest for NRM workers, and NRCTI is highest for NRC workers. The share of censored spells in our sample amounts to 12.62 percent. In comparison, most censored spells come from NRC workers, where the share of censored spells amounts to 32.42 percent (the share of censored spells of routine workers amounts to 5.65 percent, while the share of censored spells of NRM workers amounts to only 2.47 percent). The share of foreign workers among all NRM workers is relatively high compared to the other task groups. NRM workers are also more likely to work with foreign workers and low-skilled workers in their respective firms, while NRC workers have more high-skilled co-workers. In comparison to the other task groups, a relatively high share of routine workers is in small firms and a distinctively high share of routine workers work in manufacturing, while a high share of NRC workers is employed in large or very large firms. A 
relatively high share of NRC workers works in district-free cities. A high share of routine workers works in urban districts, but in comparison to the other task groups are also relatively likely to work in rural districts.

\section{Results}

\section{A. Monopsony Power by Task Groups}

As described in Section III, we start by estimating the labor supply elasticities to the firm for three task groups (routine, NRM and NRC workers) for the whole observation period. Thus, we estimate Cox models for the separation rates to employment and non-employment, and logit models for the probability that a worker is hired from employment (as opposed to non-employment) separately for these three groups. Our key independent variable in each of these estimations is log wages. Inserting the estimated wage elasticities from these models as well as the share of hires from employment into Equation 4 yields estimates of the firm-level labor supply elasticity.

Table 2 shows that the wage elasticity of labor supply to the firm is distinctly smaller for NRC workers (0.958) than for the other task groups (1.696 for routine workers and 1.659 for NRM workers), which implies a higher degree of monopsony power towards NRC workers. ${ }^{13}$ The results in Table 2 also indicate that the components of the estimated labor supply elasticities differ considerably between task groups.

To quantify the contribution of the individual components to the overall differences in the labor supply elasticity between task groups, we apply the decomposition proposed by Hirsch and Jahn (2015). In doing so, we focus on the routine-NRC and NRM-NRC differences. ${ }^{14} \mathrm{We}$ find that the most important component driving the difference in the firm-level labor supply elasticities between NRC workers and the other task groups is the separation rate elasticity to employment 
(see Table 3). This component contributes almost 69 percent to the lower firm-level labor supply elasticity of NRC workers relative to routine workers, and about 56 percent to the difference between NRM and NRC workers. Hence, job-to-job transitions of NRC workers are much less wage-driven than is the case for other task groups. Separations to non-employment are also less wage-elastic for NRC workers than for routine and NRM workers (see Table 2). This component accounts for almost 27 percent of the difference in firm-level labor supply elasticities between routine and NRC workers, and for almost 30 percent of the difference between NRM and NRC workers.

The wage elasticity of the share of recruits hired from employment is highest for NRC workers. It thereby contributes to the lower labor supply elasticity of NRC workers in comparison to the other two task groups. However, the magnitude of the contribution differs: For the routineNRC difference, it accounts for only 12.5 percent, while the contribution is significantly higher at 35 percent for the NRM-NRC difference in labor supply elasticities. Thus, by increasing the wage, employers raise the share of hires from employment to a greater extent for NRC workers than for routine and (especially) NRM workers.

Finally, the share of hires from employment which is used to weight the different components in the firm-level labor supply elasticity equation mitigates the difference between NRC workers and the other task groups. This mitigating effect of the share of hires from employment for the difference in firm-level labor supply elasticities is much more pronounced for the NRMNRC than for the routine-NRC difference. NRC workers are more likely to be hired from employment than routine and particularly than NRM workers.

Summarizing, our results based on the approach using three task groups with a fixed classification over time are as follows. First, the lowest wage elasticity of labor supply to the firm, 
that is, the highest degree of monopsony power, can be observed for NRC workers. Second, this result is mainly due to the lower separation rate elasticity to employment of NRC workers. Third, the share of hires from employment acts as a mitigating factor in the difference of the firm-level labor supply elasticity between NRC workers and workers in other task groups.

\section{B. Monopsony Power and Task Intensities}

In our second estimation approach, we estimate a model including all workers, and interact the wage variable with three task intensity (TI) measures: routine TI (RTI), non-routine manual TI (NRMTI), and non-routine cognitive TI (NRCTI). These time-varying TI measures are assigned to individual workers according to their occupation. This allows us to study the influence of the TI on the labor supply elasticity to the firm on a continuous scale. More details on how we construct task intensities are provided in Section IV.B.

The results obtained from this estimation approach (Table 4) are in line with those based on the separate estimations by task group presented in the preceding section: The labor supply elasticity of workers performing jobs with high RTI, that is, workers with one standard deviation above the mean RTI value in the sample, equals 2.288 . In contrast, the labor supply elasticity of workers performing jobs with low RTI, that is, workers with one standard deviation below the mean RTI value in the sample, is much lower and equals $1.103 .{ }^{15} \mathrm{Next}$, we use our continuous measures NRMTI and NRCTI in Table 4 to distinguish between non-routine jobs that are cognitive in nature and non-routine jobs that are manual in nature. Workers with high NRMTI have a labor supply elasticity of 1.852, while workers with high NRCTI have a significantly lower labor supply elasticity of $0.985 .{ }^{16}$ Again, the results show that all components, apart from the share of hires from employment, contribute to the lower labor supply elasticity for workers with high NRCTI in 
comparison to workers that have a high RTI or NRMTI. Similarly to the results in Table 3, especially the separation rate elasticity to employment is much smaller for workers with high NRCTI than for high RTI or high NRMTI workers.

We perform multiple robustness checks for the estimations in Table 4 that are presented in the Online Appendix (Section B.4). ${ }^{17}$ First, we estimate a full-interaction model in which we interact the TI variable with every control variable in the specification. We find that the results are robust to this specification and that the main results still hold when the coefficients of all covariates are allowed to vary with TI. Second, we use sector-year (interacted) fixed effects so that identification uses only wage variation within sector-year cells. The results in Table 4 are robust to this specification. Third, we analyze if the estimated differences in monopsony power for workers with different task intensities are simply driven by the workers' location in the wage distribution. The different location in the wage distribution is relevant as the theoretical model of Burdett and Mortensen (1998) suggests that the labor supply elasticity is falling in wages. To alleviate this concern, we estimate the labor supply elasticity to the firm separately by wage brackets and task intensities. Hence, we compare workers with different task intensities at the same points of the wage distribution. Reassuringly, we find that our general result (workers in occupations with high NRCTI have lower labor supply elasticities to the firm) holds even when we compare workers at the same position of the wage distribution.

Given that separate estimations by task groups or interacting wages with task intensities lead to qualitatively similar results, we focus on task intensities in the remaining estimations for two reasons. First, the TI variables are continuous and therefore contain more information on the task content of the worker. Second, the TI measures are updated over time, taking into account that 
the task content of each occupation changes during the observation period, possibly to a different degree (see Section IV.B).

We now turn to the question to which extent the estimated labor supply elasticity to the firm changes over time and if there are differences in this trend by RTI. To do so, we add a three-way interaction to the model using RTI (Table 4). That is, we interact the wage variable, RTI, and year dummies $^{18}$, which allows us to trace the evolution of $\log$ wage ${ }^{*}$ RI over time. For ease of interpretation, Figure 1 plots the obtained yearly labor supply elasticities for workers with low, mean, and high RTI. Clearly, the level differences between workers with low and high RTI found for the pooled sample in Table 4 persist, that is, workers with low RTI have lower yearly labor supply elasticities to the firm than workers with high RTI. These differences vary over time, and the labor supply elasticities display a markedly procyclical variation, which confirms the results in Depew and Sørensen (2013) and Hirsch, Jahn, and Schnabel (2018).

Overall, cyclical movements in the elasticity of labor supply to the firm appear to be more important than long-run trends. There is some indication in Figure 1 that the labor supply elasticity has been increasing from 2003 onwards. However, it would be premature to interpret this rise as a structural shift in labor market competition, as the German labor market experienced no significant downturn during this time period. This rise could therefore simply be due to good economic conditions, which have generally been found to reduce monopsony power. Even more importantly for our purpose, the increase in the labor supply elasticity is of equal magnitude for workers with low and high RTI. We therefore conclude that labor market polarization, in terms of decreasing outside options for workers with high RTI, has not influenced the degree of monopsony power faced by routine workers to an important degree. ${ }^{19}$ 
Looking at the components of the labor supply elasticity over time for workers with different RTI levels, we also find no pronounced long-run trend for the separation rate elasticities and the elasticity of the share of recruits from employment. ${ }^{20}$ The only component that changes more strongly, the share of recruits from employment, plays the least important role for differences between task groups. Therefore, the relative contributions of the components of the labor supply elasticity to the firm are rather unchanged over time.

We provide two robustness checks for the results obtained in Figure 1. First, instead of estimating yearly labor supply elasticities, we use time windows of three years, thereby smoothing the estimates and making them less vulnerable to short-term fluctuations. Appendix Figure A.1 shows that the general pattern over time is comparable to our yearly estimates, and that the differences by RTI still persist. ${ }^{21}$

Second, up to this point, in our estimations we have used all the variation in wages and transition rates, both across and within workers. The separation rate elasticities may alternatively be estimated with stratified Cox models, in which the baseline hazard $h_{m(i) 0}(t)$ is stratified at the worker level. Similarly to the within estimator in linear fixed-effects models, this cancels out the worker-specific effect (Ridder and Tunal1 1999). ${ }^{22}$ Furthermore, in this robustness test we also use a conditional logit (or fixed-effects logit) model to arrive at an estimate of the wage elasticity of the share of recruits hired from employment. ${ }^{23}$ Appendix Figure A.2 shows the estimated labor supply elasticities for each year and by RTI using only within-worker variation. There are two important differences to the results from our baseline model. First, the estimated labor supply elasticities for workers of all RTI levels are higher at the beginning of the observation period and decline sharply from 1985-98 and increase thereafter. Second, differences between workers with low and high RTI are smaller. However, we still find workers with high RTI at their job to show 
higher labor supply elasticities than workers with low RTI. Our general findings are therefore robust to using only within-worker variation.

Generally, we prefer the estimates based on the Cox model over those obtained from the stratified Cox model for two reasons. First, the stratified Cox model only includes workers in the estimation sample that have at least two employment spells ending in the same transition, which implies that the estimation sample is smaller, and possibly more selective, than the estimation sample of the Cox model without stratification. As workers with different RTI levels could well differ in this respect - for example there may be more non-routine workers who display the required transitions - this kind of sample selection is likely to lead to an estimation bias. Therefore, using the entire sample, that is, estimating without stratification, seems more appropriate. Second, the variation used in the stratified Cox model is purely within-worker variation. Given that workers generally change to jobs with a low task distance (Gathmann and Schönberg 2010), the withinworker variation in RTI is much smaller than the between-worker variation used in the Cox model without stratification. However, to answer our research questions, comparing workers with different RTI levels seems crucial. Based on these considerations and because the results obtained using between-worker and within-worker variation do not differ qualitatively, we analyze the mechanisms potentially driving differences in monopsony power by task intensities using the Cox model.

\section{Mechanisms}

In this section, we explore different mechanisms that may explain our results on the level differences in monopsony power between task groups: collective bargaining agreements, jobspecific human capital, and non-pecuniary job characteristics. 


\section{Differences by collective bargaining coverage}

An important labor-market institution that potentially influences level differences in monopsony power is collective bargaining. Collective bargaining agreements typically increase wages of lowwage workers and compress the industry's wage distribution. This does not necessarily influence any of the sources of monopsony but prevents firms from exercising their monopsony power (Manning 2003), thereby increasing the estimated labor supply elasticities. Bachmann and Frings (2017) confirm this idea by showing that the estimates of the labor supply elasticity are larger in industries with higher collective bargaining coverage in Germany.

Collective bargaining coverage varies to a large degree at the industry level in Germany. For example, collective bargaining coverage amounts to 91 percent in the public services industry and to 37 percent in transportation and logistics for West Germany in 2016 (WSI 2018). This might affect our estimates of the labor supply elasticity by TI in two ways. First, to the extent that workers with different TI are not randomly distributed across industries, these differences might be driving the link between TI and the labor supply elasticity to the firm. In this case, we should observe much smaller differences in labor supply elasticities by TI within industries than in the whole sample. Second, differences in monopsony power by TI might be influenced by collective bargaining coverage at the industry level, because for instance routine workers are much more often low-wage workers compared to non-routine cognitive workers. Additionally, due to their public nature, collective bargaining agreements can decrease information asymmetries with respect to wages, but not necessarily with respect to non-pecuniary job characteristics that are not part of the collective bargaining process. Thus, we expect collective bargaining agreements to increase the labor supply elasticity of routine workers, but not so much for NRC workers. In this case, we should observe an 
increase in the labor supply elasticity for routine workers only in industries with a high coverage rate of collective bargaining.

To differentiate between these two channels through which collective bargaining coverage influences the estimated labor supply elasticities by TI, we choose three industries with high ${ }^{24}$ and three industries with low ${ }^{25}$ collective bargaining coverage, while ensuring that each industry employs workers with varying TI. We omit industries with average collective bargaining coverage because possible differences in the relationship between TI and monopsony power will be easier to detect in the tails of the collective bargaining coverage distribution. Also, this allows us to neglect changes over time in bargaining coverage. We then run our baseline model for both groups of industries separately. ${ }^{26} \mathrm{We}$ summarize our results in Table $5 .{ }^{27}$

In line with theoretical expectations, Table 5 shows that the labor supply elasticity to the firm is much lower in industries with a low coverage rate of collective bargaining. The labor supply elasticity decreases by about 63 percent for workers with high NRCTI from high collective bargaining coverage industries to low collective bargaining coverage industries, while it decreases by about 31 percent for workers with high RTI and 18 percent for workers with high NRMTI. This indicates that collective bargaining status has a strong counteracting effect on the monopsony power of firms, especially for workers with high NRCTI. However, the differences in labor supply elasticities for workers with high RTI, high NRMTI, and high NRCTI persist independently of collective bargaining coverage. We can thus draw two conclusions: First, our main results are not strongly driven by composition effects with respect to industries. Second, collective bargaining coverage does not influence differences in monopsony power between task groups. 


\section{The role of job specific human capital}

In Section II we argue that job-specific human capital is an important source of monopsony power in the labor market. Workers who have accumulated a high amount of job-specific human capital can be expected to have a relatively low incentive to switch jobs to improve their wage. Hence, as workers do not want to lose their accumulated job-specific human capital, the labor supply elasticity to the firm with respect to wages can be expected to decrease with higher job-specific human capital, thereby increasing the monopsony power of employers.

Job-specific human capital should be more important as a source of monopsony power for NRC workers than for other task groups as NRC workers perform more complex tasks at their job (Acemoglu and Autor 2011; Booth and Zoega 2008). Gathmann and Schönberg (2010) propose the concept of task-specific human capital - which is strongly related to job-specific human capital - and show that workers generally move to occupations with similar task requirements. Workers lose task-specific human capital if the tasks in the new job are very different from the old one. We expect that NRC workers have a lower arrival rate of job offers suiting their current task profile which is relatively complex. We further expect that NRC workers have a low incentive to switch to a new job in which they perform different tasks than in their current job because this would imply a relatively large loss of job-specific human capital. In consequence, the labor supply elasticity to the firm with respect to wages is likely to be lower for NRC workers than for other task groups, that is NRC workers are likely to be exposed to a higher degree of monopsony power.

To provide evidence regarding these hypotheses, we estimate the separation rate elasticities for workers in different job tenure brackets - proxying different degrees of accumulated jobspecific human capital - and with different task intensities. We focus on the separation rate elasticities because all job-specific human capital is lost once a worker quits his job. Therefore, the 
separation rate elasticities are the components of the labor supply elasticity to the firm in Equation 4 which are most directly related to job-specific human capital. Table 6 presents the results for the separation rate elasticities for different job tenure brackets and workers with different task intensities. $^{28}$

All estimated elasticities are small in comparison to the baseline results in Appendix Table A. 1 , because the correlation between separations and log wages is - by construction - smaller within tenure brackets than across all tenure brackets. ${ }^{29}$ It is therefore not possible to interpret the size of the elasticities, but it is possible to compare differences in the elasticities between task groups within each tenure bracket. Analyzing the separation rate elasticity to employment in more detail, we find for the first tenure bracket (0-3 years) that the elasticity is twice as high for high-RTI workers than for high-NRCTI workers. In the last tenure bracket $(10+$ years $)$, the separation rate elasticity of high-RTI workers is 3.6 times higher than the elasticity of high-RTI or high-NRMTI workers. This means that the relative difference in the separation rate elasticities to employment almost doubles as tenure increases. Noticeably, there are hardly any differences between high-RTI and high-NRMTI workers. For the elasticity of the separation rate to non-employment, we generally find the same pattern but the differences between high-NRCTI and high-RTI/NRMTI workers do not increase as strongly across tenure brackets.

In sum, this exercise provides suggestive evidence that high-NRCTI workers value jobspecific human capital more strongly when considering a separation to employment than workers performing routine or NRM tasks. At the same time, job-specific human capital is less important to high-NRCTI workers when considering a separation to non-employment. Therefore, for highNRCTI workers, job-specific human capital has an important impact on separations to employment which contributes to the relatively high monopsony power these workers are facing. 


\section{The role of non-pecuniary job characteristics}

As we discuss in Section II, non-pecuniary job characteristics are likely to differ between workers performing different job tasks, and therefore to lead to different levels of monopsony power between these workers. In the following, we therefore analyze the prevalence of specific nonpecuniary job characteristics by task intensities and the change in these job characteristics over time. The BIBB data described in Section IV.B allow us to do so because the dataset not only contains information on job tasks, but also on various non-pecuniary job characteristics and on workers' satisfaction with those characteristics. Specifically, we construct several dependent variables which capture to what extent a non-pecuniary characteristic (for example satisfaction with promotion opportunities) is present. This generally results in ordinal discrete variables with more than two outcomes and natural ordering. We regress these dependent variables on task group dummies and additional control variables separately for each BIBB wave. ${ }^{30}$

The results from this exercise are presented in Table 7. Panel A shows that NRC workers are less likely to work in unfavorable physical working conditions such as extreme temperatures, noise, and unfavorable body positions relative to routine workers, which is in line with expectations. For example, the odds ratio of answering the question of whether one works in a physically unfavorable position with high approval versus the combined lower approval categories is 0.456 times lower for NRC workers than for routine workers in 1985.

Panel B of Table 7 features questions on the mental working conditions of workers such as working under strong deadline or performance pressure, perceiving the workplace as part of a community, and cooperation with colleagues. Here we find that NRC workers are generally more likely to work under strong deadline or performance pressure than routine workers. For the 2006 
wave, we also find that NRC workers are more likely to perceive the workplace as part of a community and to appreciate the cooperation with colleagues.

Panel C of Table 7 shows the satisfaction with different non-pecuniary job characteristics of workers in different task categories. In all BIBB waves where this question was asked, we find that NRC workers are generally more likely to be satisfied with their job than routine workers. For example, the odds ratio of being very satisfied with the current job versus the combined lower satisfaction categories is 1.242 times higher for NRC workers than for routine workers in 2012. Looking at sub-categories of job satisfaction, we find that NRC workers, relative to routine workers, are generally more likely to be satisfied with their promotion opportunities, the work climate (significant for one survey wave only), the type and content of tasks at the job, the ability to use own skills, and the available training opportunities. At the same time, we do not find any higher likelihood for NRM workers in panel C, indicating that they are either equally or less satisfied than routine workers.

Summarizing, the descriptive evidence in Table 7 shows that NRC workers enjoy better non-pecuniary job characteristics and there is no indication for trends over time. Our results complement the literature on non-pecuniary job characteristics which shows that workers are willing to accept lower wages in exchange for better non-pecuniary working conditions (see for example Mas and Pallais 2017; Maestas et al. 2018) and sometimes make a transition to jobs with lower wages compensated with better non-pecuniary job characteristics (Sullivan and To 2014; Sorkin 2018). Our estimation results indicate that non-pecuniary job characteristics are more important for NRC workers than for other worker groups. This in turn implies that wages play a smaller role in the mobility decisions of NRC workers. Therefore, employers have higher wage- 
setting power towards NRC workers because of non-pecuniary job characteristics. These job characteristics are therefore an important source of monopsony power for NRC workers.

\section{Conclusion}

In this paper, we investigate the link between technological change and job tasks on the one hand, and the degree of monopsony power on the other hand. To estimate the degree of monopsony power, we use the semi-structural estimation approach proposed by Manning (2003), which allows us to identify the wage elasticity of labor supply to the firm. Our analysis is based on two unique data sets from Germany: an administrative data set on individual labor market histories spanning the years 1985-2014 which provides exact information on wages and labor market transitions; and worker-level survey data on job tasks which allows us to compute time-varying measures of job task intensities at the occupational level, and which we merge to the administrative data set. This approach goes beyond many papers in the job task literature as we are able to measure intensities for routine, non-routine cognitive (NRC) and non-routine manual (NRM) job tasks on a continuous scale, and to account for changes in task intensities over time.

Our results indicate that workers who perform jobs with a high routine task content face a higher wage elasticity of labor supply to the firm than workers performing mainly NRC tasks. This means that workers specializing in NRC tasks are subject to higher monopsony power by employers. When decomposing the wage elasticities for routine, NRC, and NRM workers, we find that this result mainly arises because NRC workers react much less to wages in their decision to separate to employment than routine workers.

When analyzing the evolution of monopsony power over time, we find no long-run trends in the labor supply elasticity to the firm for any worker group, including high-RTI workers, and 
therefore conclude that the de-routinization of the labor market has not influenced the degree of monopsony power faced by routine workers to a significant degree. This result is somewhat surprising: as explained in Section II, in a Burdett and Mortensen (1998)-type of labor market, we would have expected the lower demand for routine workers to decrease the job offer arrival rate for these workers resulting in less job mobility, with additional amplification effects reinforcing the original demand factors and leading to an increase in monopsony power. Such amplification effects can arise because workers in declining task groups become more risk averse in their mobility decisions. Given that we observe a relatively constant labor supply elasticity over time, we can conclude that there are no amplification effects in the long run.

There are two possible explanations for our result of a relatively constant monopsony power. First, there could be composition effects, which are neglected in the Burdett and Mortensen (1998) model which assumes ex ante identical workers. As shown by Böhm, von Gaudecker, and Schran (2019) recently, workers leaving shrinking occupations and entering growing occupations are predominantly low-wage (relative to their peer group). These labor-market transitions have a composition effect for occupations: In shrinking occupations, average worker quality rises. Therefore, the job-offer arrival rate to workers in shrinking occupations can be expected not to decline as strongly, because firms know that the workers remaining in these occupations are (relatively) high-skilled workers with high productivity, and hence try to poach them from rivals. While this seems a potential explanation in this context, the results on our analysis on non-wage job characteristics do not indicate large composition effects. Second, our research question relates to long-run developments as opposed to the studies on the cyclicality of monopsony power such as Hirsch, Jahn, and Schnabel (2018) or Webber (2020) who find monopsony power to react to changes in demand. It seems conceivable that workers react very differently to short-term changes 
in demand such as business cycle developments than they do in response to long-run changes such as the polarization of the labor market. Analyzing these two potential explanations for our finding are therefore important avenues for future research.

In the final part of our analysis, we explore potential mechanisms leading to level differences in monopsony power between workers performing different job tasks, especially to explain the higher monopsony power towards NRC workers. An analysis of the separation elasticity to employment by tenure bracket indicates that job-specific human capital plays a more important role for NRC workers, which increases firms' monopsony power towards these workers. Furthermore, non-pecuniary job characteristics such as working conditions and job satisfaction seem to play a much more important role for NRC workers, again increasing firms' monopsony power towards these workers. Finally, we find that the labor supply elasticity to the firm is much lower in industries with a low coverage rate of collective bargaining than in industries with a high coverage rate of collective bargaining. However, the differences in monopsony power between worker groups are not driven by composition effects in terms of industries employing workers with varying levels of task intensities. Therefore, unions do not seem to play a role for differences in monopsony power between workers performing different job tasks.

Our results have two important implications. First, the cross-sectional differences in monopsony power show that job tasks are another individual-level dimension in explaining wage gaps between worker groups, similar to earlier results in the literature, for instance with respect to gender or nationality. Our results suggest that controlling for job tasks could provide an additional explanation for monopsony power workers face, and hence for the resulting wage gaps. Second, our finding that monopsony power does not display a long-run trend may come as a surprise, particularly with respect to routine workers, as the job opportunities of routine workers have 
declined strongly in recent decades with ongoing labor market polarization caused by technological progress. Nevertheless, our results imply that changes in monopsony power do not seem to be a factor contributing to increased labor-market inequality in Germany in recent decades. 


\section{References}

Acemoglu, Daron, and David Autor. 2011. "Skills, Tasks and Technologies: Implications for Employment and Earnings." In Handbook of Labor Economics, Volume 4B, ed. Orley Ashenfelter and David Card, 1043-1171. Amsterdam: Elsevier.

Acemoglu, Daron, and Pascual Restrepo. 2018. "The Race between Man and Machine: Implications of Technology for Growth, Factor Shares, and Employment." American Economic Review 108(6): 1488-1542.

Antonczyk, Dirk, Bernd Fitzenberger, and Ute Leuschner. 2009. “Can a Task-Based Approach Explain the Recent Changes in the German Wage Structure?" Jahrbücher für Nationalökonomie und Statistik 229(2-3): 214-238.

Antoni, Manfred, Andreas Ganzer, and Philipp Vom Berge. 2016. "Sample of Integrated Labour Market Biographies (SIAB) 1975-2014." FDZ-Datenreport 4, Nuremberg: Institute for Employment Research.

Autor, David H., David Dorn, Lawrence F. Katz, Christina Patterson, and John Van Reenen. 2020. "The Fall of the Labor Share and the Rise of Superstar Firms." The Quarterly Journal of Economics 135(2): 645-709.

Autor, David H., and David Dorn. 2013. "The Growth of Low-Skill Service Jobs and the Polarization of the US Labor Market." American Economic Review 103(5): 1553-97.

Autor, David H., Frank Levy, and Richard J. Murnane. 2003. "The Skill Content of Recent Technological Change: An Empirical Exploration." The Quarterly Journal of Economics 118(4): 1279-1333.

Azar, José, Ioana Marinescu, and Marshall Steinbaum. 2020. "Labor Market Concentration." Journal of Human Resources. Forthcoming.

Bachmann, Ronald, Merve Cim, and Colin Green. 2019. "Long-Run Patterns of Labor Market Polarization: Evidence from German Micro Data.” British Journal of Industrial Relations 57(2): 350-376.

Bachmann, Ronald, and Hanna Frings. 2017. "Monopsonistic Competition, Low-Wage Labor Markets, and Minimum Wages-An Empirical Analysis.” Applied Economics 49(51): 52685286. 
Bassier, Ihsaan, Arindrajit Dube, and Suresh Naidu. 2020. "Monopsony in Movers: The Elasticity of Labor Supply to Firm Wage Policies.” NBER Working Paper 27755.

Baumgarten, Daniel. 2015. "Offshoring, the Nature of Tasks, and Occupational Stability: Empirical Evidence for Germany." The World Economy 38(3): 479-508.

Bender, Stefan, Jürgen Hilzendegen, Rohwer Götz, and Helmut Rudolph. 1996. „Die IABBeschäftigtenstichprobe 1975-1990.“ Beiträge zur Arbeitsmarkt- und Berufsforschung 19, Nuremberg: Bundesanstalt für Arbeit.

BIBB - Federal Institute for Vocational Education and Training. 2021. BIBB/BAuA Employment Survey. Online: https://www.bibb.de/de/2815.php. Accessed on 14/2/2021.

Böhm, Michael J., Hans-Martin von Gaudecker, and Felix Schran. 2019. "Occupation Growth, Skill Prices, and Wage Inequality.” IZA Discussion Paper 12647.

Booth, Alison L., and Pamela Katic. 2011. "Estimating the Wage Elasticity of Labour Supply to a Firm: What Evidence is there for Monopsony?" Economic Record 87(278): 359-69.

Booth, Alison L., and Gylfi Zoega. 2008. "Worker Heterogeneity, New Monopsony, and Training." Labour 22(2): 247-270.

Brenzel, Hanna, Hermann Gartner, and Claus Schnabel. 2014. "Wage Bargaining or Wage Posting? Evidence from the Employers' Side.” Labour Economics 29(1): 41-48.

Burdett, Kenneth, and Dale T. Mortensen. 1998. "Wage Differentials, Employer Size, and Unemployment." International Economic Review 39(2): 257-73.

Card, David, Jörg Heining, and Patrick Kline. 2013. "Workplace Heterogeneity and the Rise of West German Wage Inequality.” The Quarterly Journal of Economics 128(3): 967-1015

Cortes, Guido M. 2016. "Where Have the Middle-Wage Workers Gone? A Study of Polarization Using Panel Data." Journal of Labor Economics 34(1): 63-105.

Cortes, Guido M., and Giovanni Gallipoli. 2018. "The Costs of Occupational Mobility: An Aggregate Analysis." Journal of the European Economic Association 16(2): 275-315.

Depew, Briggs, and Todd A. Sørensen. 2013. "The Elasticity of Labor Supply to the Firm over the Business Cycle." Labour Economics 24: 196-204.

Dustmann, Christian, Johannes Ludsteck, and Uta Schönberg. 2009. "Revisiting the German Wage Structure." The Quarterly Journal of Economics 124(2): 843-881.

Eberle, Johanna, Peter Jacobebbinghaus, Johannes Ludsteck, and Julia Witter. 2011. "Generation of Time-Consistent Industry Codes in the Face of Classification Changes. Simple Heuristic 
Based on the Establishment History Panel (BHP).” FDZ-Methodenreport 5, Nuremberg: Institute for Employment Research.

Fitzenberger, Bernd, Aderonke Osikominu, and Robert Völter. 2006. "Imputation Rules to Improve the Education Variable in the IAB Employment Subsample." Schmollers Jahrbuch 126(3):405-36.

Gartner, Hermann. 2005. "The Imputation of Wages above the Contribution Limit with the German IAB Employment Sample." FDZ-Methodenreport 2, Nuremberg: Institute for Employment Research.

Gathmann, Christina, and Uta Schönberg. 2010. "How General is Human Capital? A Task-Based Approach." Journal of Labor Economics 28(1): 1-49.

Goos, Maarten, and Alan Manning. 2007. "Lousy and Lovely Jobs: The Rising Polarization of Work in Britain." The Review of Economics and Statistics 89(1): 118-133.

Goos, Maarten, Alan Manning, and Anna Salomons. 2009. "Job Polarization in Europe." American Economic Review 99(2): 58-63. 2014. "Explaining Job Polarization: Routine-Biased Technological Change and Offshoring." American Economic Review 104(8): 2509-26.

Hethey-Maier, Tanja, and Johannes F. Schmieder. 2013. "Does the Use of Worker Flows Improve the Analysis of Establishment Turnover: Evidence from German Administrative Data." Schmollers Jahrbuch 133(4): 477-510.

Hirsch, Boris, and Elke J. Jahn. 2015. "Is There Monopsonistic Discrimination Against Immigrants?" ILR Review 68(3): 501-528.

Hirsch, Boris, Elke J. Jahn, Alan Manning, and Michael Oberfichtner. 2020. "The Urban Wage Premium in Imperfect Labor Markets." Journal of Human Resources. Forthcoming.

Hirsch, Boris, Elke J. Jahn, and Claus Schnabel. 2018. "Do Employers Have More Monopsony Power in Slack Labor Markets?" ILR Review 71(3): 676-704.

Hirsch, Boris, Thorsten Schank, and Claus Schnabel. 2010. "Differences in Labor Supply to Monopsonistic Firms and the Gender Pay Gap: An Empirical Analysis Using Linked Employer-Employee Data from Germany.” Journal of Labor Economics 28(2): 291-330.

Kalbfleisch, John D., and Ross L. Prentice. 2002. The Statistical Analysis of Failure Time Data. Hoboken, NJ: John Wiley \& Sons, 2nd edition. 
Lamadon, Thibaut, Magne Mogstad, and Bradley Setzler. 2019. "Imperfect Competition, Compensating Differentials and Rent Sharing in the US Labor Market." NBER Working Paper 25954.

Maestas, Nicole, Kathleen J. Mullen, David Powell, Till Von Wachter, and Jeffrey B. Wenger. 2018. "The Value of Working Conditions in the United States and Implications for the Structure of Wages.” NBER Working Paper 25204.

Manning, Alan. 2003. Monopsony in Motion: Imperfect Competition in Labor Markets. Princeton, NJ: Princeton University Press.

Mas, Alexandre, and Amanda Pallais. 2017. "Valuing Alternative Work Arrangements." American Economic Review 107(12): 3722-59.

Ridder, Geert, and İnsan Tunal1. 1999. "Stratified Partial Likelihood Estimation." Journal of Econometrics 92(2):193-232.

Rosen, Sherwin. 1986. "The Theory of Equalizing Differences." Handbook of labor economics 1: 641-692.

Sokolova, Anna, and Todd Sørensen. 2021. "Monopsony in Labor Markets: A Meta-Analysis." ILR Review 74(1): 27-55.

Sorkin, Isaac. 2018. "Ranking Firms Using Revealed Preference." The Quarterly Journal of Economics 133(3): 1331-1393.

Sullivan, Paul, and Ted To. 2014. "Search and Nonwage Job Characteristics." Journal of Human Resources 49(2): 472-507.

Tiemann, Michael, Hans-Joachim Schade, Robert Helmrich, Anja Hall, Uta Braun, and Peter Bott. 2008. "Berufsfeld-Definitionen des BIBB." Wissenschaftliche Diskussionspapiere 105.

Webber, Douglas A. 2015. "Firm Market Power and the Earnings Distribution." Labour Economics 35: 123-134.

. 2020. "Employment Adjustment Over the Business Cycle: The Impact of Competition in the Labor Market," Journal of Human Resources. Forthcoming.

WSI - Wirtschafts- und Sozialwissenschaftliches Institut, Düsseldorf. 2018. https://www.boeckler.de/wsi-tarifarchiv_2257.htm. Accessed: 15/11/2018.

Zwick, Thomas. 2011. "Seniority Wages and Establishment Characteristics." Labour Economics 18(6): 853-861. 
. 2012. "Consequences of Seniority Wages on the Employment Structure." ILR Review 65(1): 108-125. 


\section{Appendix}

Table A.1

Figure A.1

Figure A.2 


\section{Tables}

\section{Table 1}

\section{Sample Description}

\begin{tabular}{|c|c|c|c|c|c|c|c|c|}
\hline & \multicolumn{2}{|c|}{ Routine } & \multicolumn{2}{|l|}{ NRM } & \multicolumn{2}{|l|}{ NRC } & \multicolumn{2}{|c|}{ All workers } \\
\hline & Mean & $\mathrm{sd}$ & Mean & $\mathrm{sd}$ & Mean & $\mathrm{sd}$ & Mean & $\mathrm{sd}$ \\
\hline Log(daily wage) & $\overline{4.32}$ & 0.33 & 4.14 & 0.43 & 4.48 & 0.39 & 4.32 & 0.38 \\
\hline Imputed $\log ($ daily wage $)$ & 4.37 & 0.38 & 4.16 & 0.45 & 4.75 & 0.52 & 4.44 & 0.48 \\
\hline Share censored & 5.65 & & 2.47 & & 32.42 & & 12.62 & \\
\hline RTI & $\overline{0.43}$ & 0.15 & 0.36 & 0.16 & 0.26 & 0.11 & 0.38 & 0.16 \\
\hline NRMTI & 0.36 & 0.17 & 0.38 & 0.15 & 0.17 & 0.13 & 0.32 & 0.17 \\
\hline NRCTI & 0.21 & 0.18 & 0.26 & 0.19 & 0.57 & 0.18 & 0.30 & 0.23 \\
\hline Job tenure in years & 6.36 & 6.56 & 4.96 & 6.01 & 5.68 & 6.16 & 5.97 & 6.41 \\
\hline Share of high-skilled workers in firm & 5.78 & 8.91 & 5.52 & 8.31 & 17.66 & 20.56 & 8.29 & 13.26 \\
\hline Share of low-skilled workers in firm & 17.36 & 14.56 & 20.21 & 16.02 & 13.45 & 13.16 & 17.01 & 14.69 \\
\hline Share of foreign workers in firm & 9.89 & 13.84 & 13.41 & 17.33 & 8.01 & 13.69 & 10.09 & 14.57 \\
\hline Share of female workers in firm & 21.29 & 19.20 & 30.03 & 23.03 & 36.93 & 23.54 & 26.18 & 21.93 \\
\hline Share of part-time workers in firm & 5.09 & 9.15 & 8.81 & 14.15 & 10.98 & 14.02 & 7.00 & 11.59 \\
\hline Share in small firms (0-19 employees) & 24.98 & & 19.50 & & 22.73 & & 23.55 & \\
\hline Share in medium firms (20-250 employees) & 41.61 & & 44.87 & & 39.75 & & 41.77 & \\
\hline Share in large firms (251-999 employees) & 17.65 & & 18.46 & & 19.35 & & 18.16 & \\
\hline Share in very large firms $(1000+$ employees $)$ & 15.13 & & 16.52 & & 17.58 & & 15.90 & \\
\hline Missing & 0.63 & & 0.66 & & 0.60 & & 0.63 & \\
\hline Share in agriculture and forestry & $\overline{0.19}$ & & 0.16 & & 0.12 & & 0.17 & \\
\hline Share in fishery & 0.01 & & 0.00 & & 0.00 & & 0.01 & \\
\hline Share in mining industry & 1.48 & & 0.34 & & 0.38 & & 1.04 & \\
\hline Share in manufacturing industry & 42.66 & & 30.92 & & 26.23 & & 37.09 & \\
\hline Share in energy and water supply industry & 1.38 & & 0.29 & & 0.86 & & 1.08 & \\
\hline Share in construction industry & 17.46 & & 3.09 & & 2.72 & & 11.80 & \\
\hline Share in trade and repair industry & 13.66 & & 17.62 & & 12.75 & & 14.15 & \\
\hline Share in catering industry & 0.45 & & 4.63 & & 5.64 & & 2.30 & \\
\hline Share in transport and news industry & 7.72 & & 10.07 & & 2.72 & & 7.05 & \\
\hline Share in finance and insurance industry & 0.56 & & 0.35 & & 9.67 & & 2.48 & \\
\hline Share in economic services industry & 6.56 & & 17.26 & & 16.68 & & 10.59 & \\
\hline Share in public services industry & 4.25 & & 4.46 & & 4.52 & & 4.35 & \\
\hline Share in education industry & 0.42 & & 1.07 & & 4.21 & & 1.35 & \\
\hline Share in health industry & 0.82 & & 4.75 & & 8.30 & & 3.12 & \\
\hline Share in other industry & 1.74 & & 4.33 & & 4.58 & & 2.80 & \\
\hline Missing & 0.64 & & 0.66 & & 0.61 & & 0.64 & \\
\hline $\begin{array}{l}\text { Share in top } 3 \text { industries with highest } \\
\text { collective bargaining commitment }\end{array}$ & 22.27 & & 7.90 & & 16.91 & & 18.62 & \\
\hline $\begin{array}{l}\text { Share in bottom } 3 \text { industries with lowest } \\
\text { collective bargaining commitment }\end{array}$ & 21.83 & & 32.31 & & 21.11 & & 23.49 & \\
\hline Share of foreign workers & 11.60 & & 18.72 & & 6.87 & & 11.82 & \\
\hline Share without vocational training & 11.21 & & 20.46 & & 2.70 & & 10.97 & \\
\hline $\begin{array}{l}\text { Share with upper secondary school leaving } \\
\text { certificate or vocational training }\end{array}$ & 84.48 & & 73.81 & & 69.40 & & 79.38 & \\
\hline $\begin{array}{l}\text { Share with university degree or university of } \\
\text { applied sciences degree }\end{array}$ & 2.17 & & 1.63 & & 25.33 & & 7.07 & \\
\hline Missing & 2.15 & & 4.09 & & 2.57 & & 2.58 & \\
\hline Share in age group $18-25$ & 15.87 & & 18.76 & & 10.45 & & 15.20 & \\
\hline Share in age group 26-35 & 30.42 & & 31.19 & & 38.43 & & 32.28 & \\
\hline
\end{tabular}


Share in age group 36-45

Share in age group $46-55$

Share in district-free cities

Share in urban districts

Share in rural districts, some densely populated areas

Share in rural districts, sparsely populated

Missing

Number of separations to employment

Number of separations to non-employment

Number of employment spells

Number of workers

\begin{tabular}{llll}
28.45 & 27.30 & 30.02 & 28.59 \\
25.27 & 22.75 & 21.11 & 23.94 \\
\hline 29.93 & 35.96 & 41.47 & 33.47 \\
44.39 & 43.02 & 39.72 & 43.15 \\
14.16 & 12.22 & 10.48 & 13.03 \\
10.88 & 8.14 & 7.73 & 9.73 \\
0.64 & 0.66 & 0.60 & 0.63 \\
\hline 258,284 & 84,761 & 101,819 & 444,864 \\
450,502 & 168,768 & 123,420 & 742,690 \\
$3,448,117$ & 976,905 & $1,216,219$ & $5,641,241$ \\
338,384 & 164,654 & 171,454 & 465,131 \\
\hline
\end{tabular}

Source: SIAB and BHP, 1985-2014. Authors' calculations.

Notes: Employment spells are split by calendar year. Shares are expressed in percent. All statistics are estimated after dropping censored spells (except imputed wages and the share of censored spells). 
Table 2

The Labor Supply Elasticity to the Firm by Task Group

\begin{tabular}{llll}
\hline & Routine & NRM & NRC \\
\hline Separation rate to employment & & & \\
log wage $\left(\epsilon^{e}{ }_{s w}\right)$ & $-1.271^{* * *}$ & $-1.203^{* * *}$ & $-0.905^{* * * *}$ \\
& $(0.012)$ & $(0.019)$ & $(0.020)$ \\
Observations & $1,766,919$ & 497,460 & 733,684 \\
Separation rate to non-employment & & & \\
log wage $\left(\epsilon^{n}{ }_{\text {sw }}\right)$ & $-1.628 * * *$ & $-1.610^{* * *}$ & $-1.302^{* * *}$ \\
& $(0.008)$ & $(0.013)$ & $(0.015)$ \\
Observations & $3,351,798$ & 930,594 & $1,177,920$ \\
Hiring probability from employment & & & \\
log wage $\left(\frac{\epsilon_{\theta w}}{1-\theta}\right)$ & $1.737 * * *$ & $1.519 * * *$ & $1.887 * * *$ \\
& $(0.013)$ & $(0.020)$ & $(0.022)$ \\
\hline $\begin{array}{l}\text { Share of hires from employment }(\theta) \\
\text { Firm-level labor supply elasticity }\left(\epsilon_{L w}\right)\end{array}$ & 1.065 & 1.021 & 1.079 \\
\hline
\end{tabular}

Source: SIAB and BHP, 1985-2014. Authors' calculations.

Notes: Clustered standard errors at the person level in parentheses. Covariates included (see Section III for details): dummy variables for age and education groups, immigrant status, occupation fields, economic sector, worker composition of the firm (shares of low-skilled, high-skilled, female, parttime and immigrant workers in the plant's workforce), dummy variables for plant size, the average age of its workforce, year and federal state fixed effects, unemployment rate by year and federal state. $* * *, * *$ and $*$ indicate statistical significance at the 1 percent, 5 percent and 10 percent level respectively. 
Table 3

Decomposition of the Difference in the Firm-Level Labor Supply Elasticity

\begin{tabular}{|c|c|c|c|c|}
\hline Component & $\begin{array}{l}\text { Routine } \\
\text { workers' } \\
\text { estimated } \\
\text { firm-level } \\
\text { labor supply } \\
\text { elasticity }\end{array}$ & $\begin{array}{l}\text { Change in } \\
\text { percent of the } \\
\text { Routine-NRC } \\
\text { difference in } \\
\text { the labor } \\
\text { supply } \\
\text { elasticity }\end{array}$ & $\begin{array}{l}\text { NRM workers' } \\
\text { estimated firm- } \\
\text { level labor } \\
\text { supply } \\
\text { elasticity }\end{array}$ & $\begin{array}{l}\text { Change in } \\
\text { percent of the } \\
\text { NRM-NRC } \\
\text { difference in the } \\
\text { labor supply } \\
\text { elasticity }\end{array}$ \\
\hline $\begin{array}{l}\text { Routine/NRM workers' estimated firm- } \\
\text { level labor supply elasticity }\end{array}$ & 1.696 & & 1.659 & \\
\hline $\begin{array}{l}\text {...when using NRC workers' estimated } \\
\text { separation rate elasticity to } \\
\text { employment }\left(\epsilon_{s w}^{e}\right)\end{array}$ & 1.188 & -68.83 & 1.263 & -56.49 \\
\hline $\begin{array}{l}\text {...when additionally using NRC workers' } \\
\text { estimated separation rate elasticity to } \\
\text { non-employment } \\
\left(\epsilon_{s w}^{n}\right)\end{array}$ & 0.989 & -26.97 & 1.056 & -29.53 \\
\hline $\begin{array}{l}\text {... when additionally using NRC workers' } \\
\text { estimated wage elasticity of the share } \\
\text { of hires from employment }\left(\frac{\epsilon_{\theta w}}{1-\theta}\right)\end{array}$ & 0.897 & -12.50 & 0.809 & -35.28 \\
\hline $\begin{array}{l}\text {...when additionally using NRC workers' } \\
\text { estimated share of hires from } \\
\text { employment (= NRC workers' } \\
\text { estimated labor supply elasticity) }(\theta)\end{array}$ & 0.958 & +8.30 & 0.958 & +21.30 \\
\hline
\end{tabular}

Source: SIAB and BHP, 1985-2014. Authors' calculations.

Notes: The decomposition is based on estimates from Table 2. 
Table 4

The Labor Supply Elasticity to the Firm by Task Intensities (TI)

\begin{tabular}{|c|c|c|c|}
\hline & $R T I$ & $N R M T I$ & $N R C T I$ \\
\hline \multicolumn{4}{|c|}{ Separation rate to employment } \\
\hline \multirow[t]{2}{*}{$\log$ wage $\left(\epsilon_{s w}^{e}\right.$ mean TI $)$} & $-1.273 * * *$ & $-1.199 * * *$ & $-1.241 * * *$ \\
\hline & $(0.009)$ & $(0.009)$ & $(0.009)$ \\
\hline \multirow[t]{2}{*}{ log wage $\times$ TI } & $-0.315 * * *$ & $-0.181 * * *$ & $0.359 * * *$ \\
\hline & $(0.007)$ & $(0.007)$ & $(0.007)$ \\
\hline$\epsilon_{s w}^{e}($ high TI $)$ & -1.588 & -1.380 & -0.882 \\
\hline$\epsilon_{s w}^{e}($ low TI $)$ & -0.958 & -1.018 & -1.600 \\
\hline Observations & $2,998,063$ & $2,998,063$ & $2,998,063$ \\
\hline \multicolumn{4}{|c|}{ Separation rate to non-employment } \\
\hline \multirow[t]{2}{*}{ log wage $\left(\epsilon_{s w}^{n}\right.$ mean TI $)$} & $-1.612 * * *$ & $-1.570 * * *$ & $-1.582 * * *$ \\
\hline & $(0.006)$ & $(0.006)$ & $(0.006)$ \\
\hline \multirow[t]{2}{*}{ log wage $\times$ TI } & $-0.227 * * *$ & $-0.075 * * *$ & $0.222 * * *$ \\
\hline & $(0.005)$ & $(0.005)$ & $(0.005)$ \\
\hline$\epsilon_{s w}^{n}($ high TI $)$ & -1.839 & -1.645 & -1.360 \\
\hline$\epsilon_{s w}^{n}($ low TI $)$ & -1.385 & -1.495 & -1.804 \\
\hline Observations & $5,460,312$ & $5,460,312$ & $5,460,312$ \\
\hline \multicolumn{4}{|c|}{ Hiring probability from employment } \\
\hline \multirow[t]{2}{*}{ log wage $\left(\frac{\epsilon_{\theta w}}{1-\theta}\right)$} & $1.725^{* * *}$ & $1.724 * * *$ & $1.717 * * *$ \\
\hline & $(0.010)$ & $(0.010)$ & $(0.010)$ \\
\hline \multirow[t]{2}{*}{ log wage $\times$ TI } & $-0.114 * * *$ & $-0.098 * * *$ & $0.160 * * *$ \\
\hline & $(0.008)$ & $(0.008)$ & $(0.009)$ \\
\hline$\epsilon_{\theta w}($ high TI $)$ & 1.052 & 1.085 & 1.045 \\
\hline$\epsilon_{\theta w}($ mean $\mathrm{TI})$ & 1.066 & 1.069 & 1.082 \\
\hline
\end{tabular}




\begin{tabular}{llcc}
$\epsilon_{\theta w}($ low TI $)$ & 1.059 & 1.028 & 1.104 \\
Observations & 979,514 & 979,514 & 979,514 \\
Share of hires from employment $(\theta)$ & & & \\
with high TI & 0.347 & 0.333 & 0.443 \\
with mean TI & 0.382 & 0.380 & 0.370 \\
with low TI & 0.424 & 0.436 & 0.291 \\
\hline Firm-level labor supply elasticity $\left(\epsilon_{L w}\right)$ & & & \\
with high TI & 2.288 & 1.852 & 0.985 \\
with mean TI & 1.689 & 1.559 & 1.615 \\
with low TI & 1.103 & 1.277 & 2.241 \\
\hline
\end{tabular}

Source: SIAB and BHP, 1985-2014. Authors' calculations.

Notes: Clustered standard errors at the person level in parentheses. RTI, NRMTI and NRCTI are standardized with mean zero and standard deviation one. Thus, for instance workers with low RTI are workers with RTI one standard deviation below the mean, and workers with high RTI are workers with RTI one standard deviation above the mean. Same control variables as in Table 2. $* * *, * *$ and $*$ indicate statistical significance at the 1 percent, 5 percent and 10 percent level respectively. 
Table 5

The Labor Supply Elasticity to the Firm by Task Intensities and Collective Bargaining Coverage

\begin{tabular}{llcc}
\hline & High coverage & Low coverage & Baseline \\
\hline Firm-level labor supply elasticity $\left(\epsilon_{L w}\right)$ & & & \\
with high RTI & 2.010 & 1.379 & 2.288 \\
with high NRMTI & 1.510 & 1.237 & 1.852 \\
with high NRCTI & 1.044 & 0.387 & 0.985 \\
\hline
\end{tabular}

Source: SIAB and BHP, 1985-2014. Authors' calculations.

Notes: Clustered standard errors at the person level in parentheses. RTI, NRMTI and NRCTI are standardized with mean zero and standard deviation one. Thus, for instance workers with low RTI are workers with RTI one standard deviation below the mean, and workers with high RTI are workers with RTI one standard deviation above the mean. Same control variables as in Table 2. 
Table 6

Separation Rate Elasticities by Task Intensities and Tenure Brackets

\section{High RTI High NRMTI High NRCTI}

Separation rate elasticity to employment $\left(\epsilon_{s w}^{e}\right)$

Job Tenure: 0-3 years

$\begin{array}{lll}-1.066 & -0.891 \quad-0.505\end{array}$

Job Tenure: 3-10 years

$\begin{array}{lll}-0.916 & -0.783 & -0.293\end{array}$

Job Tenure: $10+$ years

$-0.698 \quad-0.678$

$-0.191$

Separation rate elasticity to non-employment $\left(\epsilon_{\text {sw }}^{n}\right)$
Job Tenure: 0-3 years
$-1.446-1.254$
$-1.058$
Job Tenure: 3-10 years
$-1.251 \quad-1.132$
$-0.803$
Job Tenure: $10+$ years
$-1.092-1.006$
$-0.705$

Source: SIAB and BHP, 1985-2014. Authors' calculations.

Notes: We use exponential models for this table. The table shows separation rate elasticities for high RTI, high NRMTI and high NRCTI workers. To compute the elasticity of high TI workers we add the coefficient of the interaction term to the coefficient of the log wage in the respective estimations. RTI, NRMTI and NRCTI are standardized with mean zero and standard deviation one. Thus, for instance workers with low RTI are workers with RTI one standard deviation below the mean, and workers with high RTI are workers with RTI one standard deviation above the mean. Same control variables as in Table 2. 


\section{Table 7}

\section{Non-Pecuniary Job Characteristics by Task Group. Odds Ratios from Regression Analysis}

\begin{tabular}{|c|c|c|c|c|c|c|c|c|c|c|}
\hline \multirow[t]{2}{*}{ Dependent Variable } & \multicolumn{2}{|l|}{1985} & \multicolumn{2}{|l|}{1992} & \multicolumn{2}{|l|}{1999} & \multicolumn{2}{|l|}{2006} & \multicolumn{2}{|l|}{2012} \\
\hline & NRM & NRC & NRM & $\mathrm{NRC}$ & NRM & NRC & NRM & $\mathrm{NRC}$ & NRM & $\mathrm{NRC}$ \\
\hline \multicolumn{11}{|l|}{ Panel A: Physical working conditions } \\
\hline Work in cold, hot, humid, wet or draught & $1.259 * * *$ & $0.484 * * *$ & $0.698 * * *$ & $0.576^{* * *}$ & 1.109 & $0.448 * * *$ & $1.219 *$ & $0.258 * * *$ & $2.467 * * *$ & $0.815^{*}$ \\
\hline conditions & $(0.078)$ & $(0.027)$ & $(0.063)$ & $(0.053)$ & $(0.077)$ & $(0.026)$ & $(0.127)$ & $(0.018)$ & $(0.234)$ & $(0.097)$ \\
\hline \multirow[t]{2}{*}{ Work under noisy conditions } & 1.095 & $0.470 * * *$ & $0.655^{* * *}$ & $0.512 * * *$ & 1.019 & $0.395 * * *$ & $0.735^{* * *} *$ & $0.241 * * *$ & $2.845^{* * *}$ & 0.992 \\
\hline & $(0.067)$ & $(0.026)$ & $(0.059)$ & $(0.047)$ & $(0.071)$ & $(0.022)$ & $(0.077)$ & $(0.017)$ & $(0.268)$ & $(0.115)$ \\
\hline \multirow[t]{2}{*}{ Work in a physically unfavorable position } & $0.845^{* * *}$ & $0.456^{* * * *}$ & $0.571^{* * *}$ & $0.626^{* * *}$ & $0.869 * *$ & $0.409 * * *$ & 0.880 & $0.329 * * *$ & $2.917 * * *$ & 1.023 \\
\hline & $(0.053)$ & $(0.027)$ & $(0.052)$ & $(0.059)$ & $(0.060)$ & $(0.024)$ & $(0.093)$ & $(0.024)$ & $(0.292)$ & $(0.131)$ \\
\hline \multicolumn{11}{|l|}{ Panel B: Mental working conditions } \\
\hline Work under strong deadline or & $0.805^{* * *}$ & $1.311^{* * *}$ & $0.723 * * *$ & $1.629 * * *$ & $0.650 * * *$ & $1.381 * * *$ & 0.998 & $1.502 * * *$ & 0.888 & 1.115 \\
\hline performance pressure & $(0.049)$ & $(0.067)$ & $(0.054)$ & $(0.127)$ & $(0.045)$ & $(0.073)$ & $(0.115)$ & $(0.114)$ & $(0.086)$ & $(0.138)$ \\
\hline Perceiving the workplace as part of a & & & & & 0.890 & 0.918 & 0.896 & $1.319 * * *$ & $0.774 * *$ & 0.997 \\
\hline community & & & & & $(0.070)$ & $(0.056)$ & $(0.121)$ & $(0.119)$ & $(0.096)$ & $(0.151)$ \\
\hline \multirow[t]{2}{*}{ Cooperation with colleagues } & & & & & & & 0.987 & $1.315^{* *}$ & 0.883 & 1.245 \\
\hline & & & & & & & $(0.171)$ & $(0.156)$ & $(0.136)$ & $(0.251)$ \\
\hline \multicolumn{11}{|l|}{ Panel C: Satisfaction } \\
\hline \multirow[t]{2}{*}{ Satisfied with job overall } & $0.650 * * *$ & $1.550 * * *$ & 0.888 & $1.484 * * *$ & & & 0.910 & $1.273 * * *$ & 0.959 & $1.242^{*}$ \\
\hline & $(0.045)$ & $(0.090)$ & $(0.079)$ & $(0.131)$ & & & $(0.111)$ & $(0.097)$ & $(0.099)$ & $(0.155)$ \\
\hline \multirow[t]{2}{*}{ Satisfied with promotion opportunities } & & & $0.748 * * *$ & $1.350 * * *$ & $0.804 * * *$ & $1.491 * * *$ & 0.870 & $1.402 * * *$ & 0.969 & 0.980 \\
\hline & & & $(0.059)$ & $(0.112)$ & $(0.057)$ & $(0.085)$ & $(0.094)$ & $(0.099)$ & $(0.093)$ & $(0.115)$ \\
\hline \multirow[t]{2}{*}{ Satisfied with work climate } & & & $0.855^{*}$ & 1.003 & $0.776 * * *$ & 1.013 & 0.968 & $1.310 * * *$ & 0.916 & 1.037 \\
\hline & & & $(0.070)$ & $(0.085)$ & $(0.058)$ & $(0.058)$ & $(0.107)$ & $(0.092)$ & $(0.087)$ & $(0.121)$ \\
\hline \multirow[t]{2}{*}{ Satisfied with the type and content of tasks } & & & $0.652 * * *$ & $1.608 * * *$ & $0.717 * * *$ & $1.568 * * *$ & 0.922 & $1.570 * * *$ & 0.947 & $1.292 * *$ \\
\hline & & & $(0.058)$ & $(0.140)$ & $(0.057)$ & $(0.093)$ & $(0.113)$ & $(0.120)$ & $(0.098)$ & $(0.162)$ \\
\hline Satisfied with the possibility to use own & & & $0.620 * * *$ & $1.598 * * *$ & $0.697 * * *$ & $1.597 * * *$ & 0.919 & $1.603 * * *$ & 1.019 & $1.267 * *$ \\
\hline skills & & & $(0.051)$ & $(0.137)$ & $(0.053)$ & $(0.095)$ & $(0.107)$ & $(0.119)$ & $(0.100)$ & $(0.152)$ \\
\hline \multirow[t]{2}{*}{ Satisfied with the training opportunities } & & & $0.742 * * *$ & $1.424 * * *$ & $0.801 * * *$ & $1.542 * * *$ & $0.794 * *$ & $1.627 * * *$ & 1.128 & $1.292 * *$ \\
\hline & & & $(0.058)$ & $(0.119)$ & $(0.057)$ & $(0.088)$ & $(0.086)$ & $(0.114)$ & $(0.107)$ & $(0.150)$ \\
\hline Number of observations & 10,384 & & 5,949 & & 8,619 & & 4,405 & & 3,274 & \\
\hline
\end{tabular}

Source: BIBB 1985, 1992, 1999, 2006 and 2012 waves. Authors' calculations.

Notes: Odds ratios from ordered logit and logit models. Results are from ordered logit models except for the 1992 wave, where logit models are used for all dependent variables in panel A. Missing cells indicate questions that were not asked in the particular BIBB 
wave. We recoded the dependent variables such that the lowest value of a variable shows a low level of approval while the highest value shows the highest level of approval. Standard errors are provided in parentheses. We include controls for federal state, sector, education, age, establishment size, immigrant worker, job tenure and job tenure squared in the estimation. Routine workers are the base category. $* * * * *$ and $*$ indicate statistical significance at the 1 percent, 5 percent and 10 percent level respectively. 
Table A. 1

The Labor Supply Elasticity to the Firm by Task Intensities (TI). Exponential Model

\begin{tabular}{|c|c|c|c|}
\hline & $R T I$ & NRMTI & NRCTI \\
\hline \multicolumn{4}{|c|}{ Separation rate to employment } \\
\hline \multirow[t]{2}{*}{ log wage $\left(\epsilon_{s w}^{e}\right.$ mean TI $)$} & $-1.454 * * *$ & $-1.376^{* * *}$ & $-1.420 * * *$ \\
\hline & $(0.011)$ & $(0.011)$ & $(0.011)$ \\
\hline \multirow[t]{2}{*}{ log wage $\times$ TI } & $-0.333 * * *$ & $-0.195 * * *$ & $0.383 * * *$ \\
\hline & $(0.009)$ & $(0.009)$ & $(0.009)$ \\
\hline$\epsilon_{s w}^{e}($ high TI $)$ & -1.787 & -1.571 & -1.037 \\
\hline$\epsilon_{s w}^{e}($ low TI $)$ & -1.121 & -1.181 & -1.803 \\
\hline Observations & $2,998,063$ & $2,998,063$ & $2,998,063$ \\
\hline \multicolumn{4}{|c|}{ Separation rate to non-employment } \\
\hline \multirow[t]{2}{*}{ log wage $\left(\epsilon_{s w}^{n}\right.$ mean TI $)$} & $-1.849 * * *$ & $-1.802 * * *$ & $-1.816^{* * *}$ \\
\hline & $(0.008)$ & $(0.008)$ & $(0.008)$ \\
\hline \multirow[t]{2}{*}{ log wage $\times$ TI } & $-0.255^{* * *}$ & $-0.106 * * *$ & $0.266 * * *$ \\
\hline & $(0.007)$ & $(0.007)$ & $(0.007)$ \\
\hline$\epsilon_{s w}^{n}($ high TI $)$ & -2.104 & -1.908 & -1.550 \\
\hline$\epsilon_{s w}^{n}($ high TI $)$ & -1.594 & -1.696 & -2.082 \\
\hline Observations & $5,460,312$ & $5,460,312$ & $5,460,312$ \\
\hline \multicolumn{4}{|c|}{ Hiring probability from employment } \\
\hline \multirow{2}{*}{ log wage $\left(\frac{\epsilon_{\theta w}}{1-\theta}\right)$} & $1.725^{* * *}$ & $1.724 * * *$ & $1.717 * * *$ \\
\hline & $(0.010)$ & $(0.010)$ & $(0.010)$ \\
\hline \multirow[t]{2}{*}{ log wage $\times \mathrm{TI}$} & $-0.114 * * *$ & $-0.098 * * *$ & $0.160 * * *$ \\
\hline & $(0.008)$ & $(0.008)$ & $(0.009)$ \\
\hline$\epsilon_{\theta w}($ high TI $)$ & 1.052 & 1.085 & 1.045 \\
\hline$\epsilon_{\theta w}($ mean TI $)$ & 1.066 & 1.069 & 1.082 \\
\hline$\epsilon_{\theta w}($ low TI $)$ & 1.059 & 1.028 & 1.104 \\
\hline Observations & 979,514 & 979,514 & 979,514 \\
\hline \multicolumn{4}{|c|}{ Share of hires from employment $(\theta)$} \\
\hline with high TI & 0.347 & 0.333 & 0.443 \\
\hline with mean TI & 0.382 & 0.380 & 0.370 \\
\hline with low TI & 0.424 & 0.436 & 0.291 \\
\hline
\end{tabular}

Firm-level labor supply elasticity $\left(\epsilon_{L w}\right)$ 

with high $T I$
2.729
2.282
1.314
with mean TI
2.086
1.947
2.008
with low TI
1.455
1.625
2.700

Source: SIAB and BHP, 1985-2014. Authors' calculations.

Notes: Clustered standard errors at the person level in parentheses. RTI, NRMTI and NRCTI are standardized with mean zero and standard deviation one. Thus, for instance workers with low RTI are workers with RTI one standard deviation below the mean, and workers with high RTI are workers with RTI one standard deviation above the mean. Same control variables as in Table 2 . ***, ** and * indicate statistical significance at the 1 percent, 5 percent and 10 percent level respectively. 


\section{Figures}

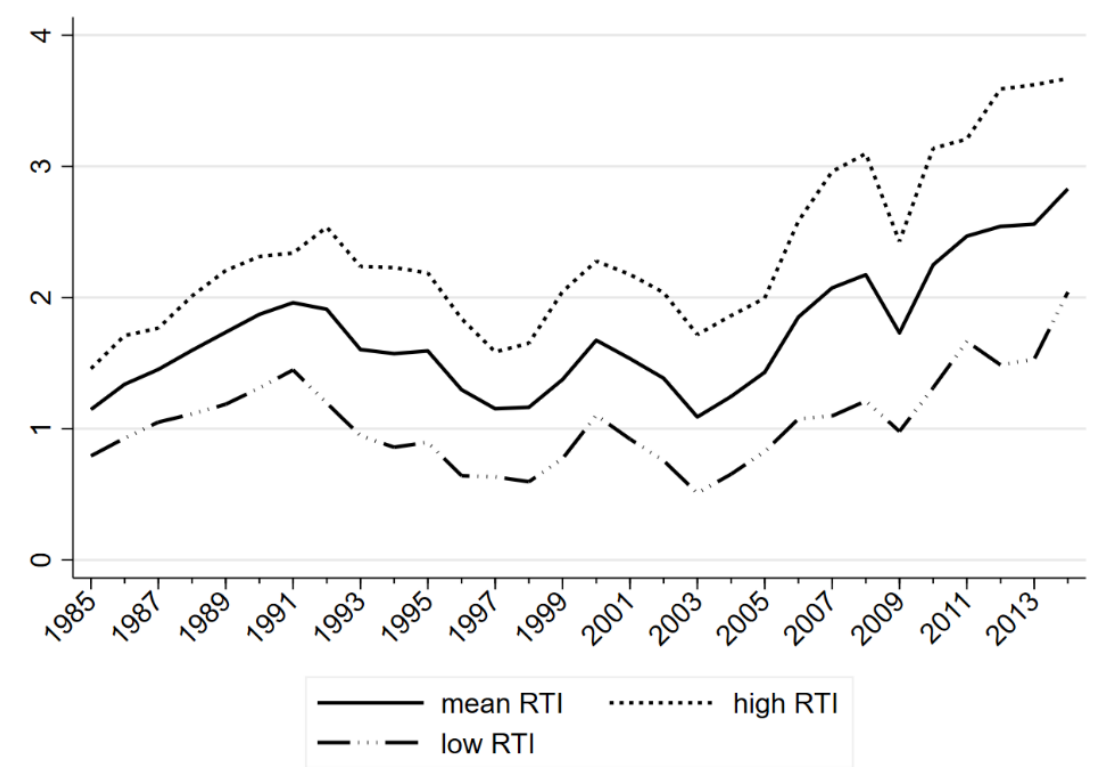

Figure 1

Yearly Labor Supply Elasticities for Workers with Different RTI

Source: Authors' calculations based on SIAB 1985-2014, for West Germany.

Notes: The estimates are derived from the same specification as in Table 4. Further, a three-way interaction with year dummies is added to analyze the development over time, that is, log wages, RTI, and year dummies are interacted. The plotted lines correspond to the sum of the relevant coefficients for workers with mean RTI as well as workers with RTI one standard deviation below ("low RTI") and above ("high RTI") the mean. 


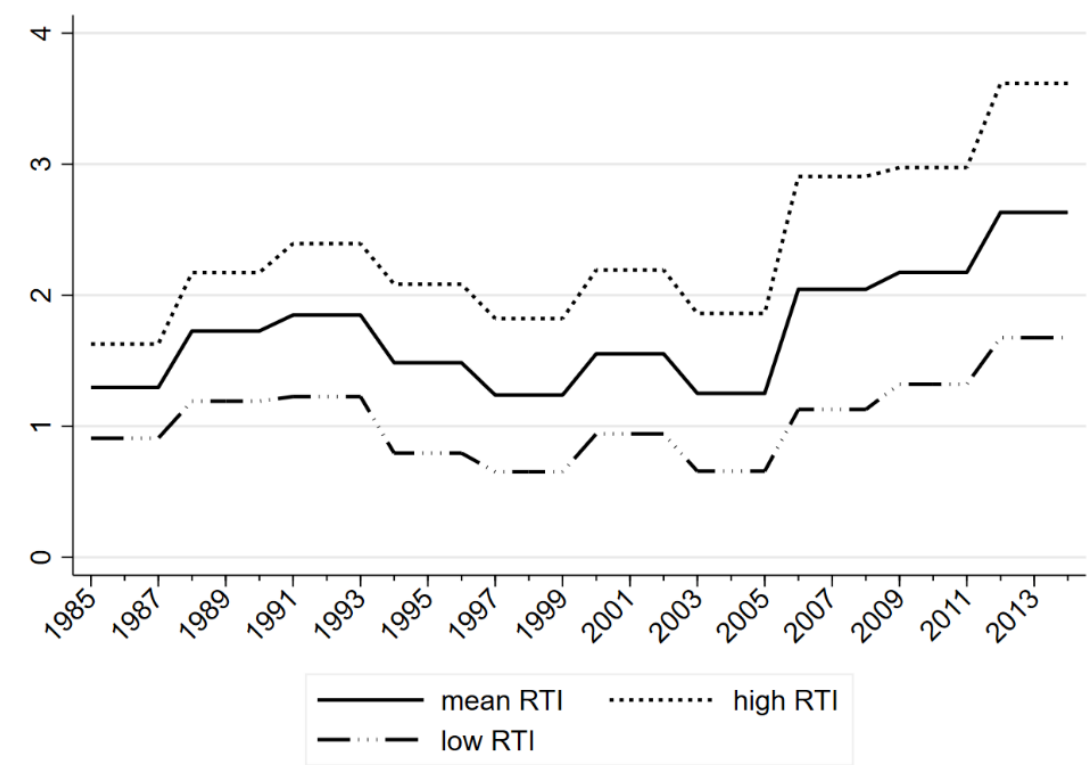

Figure A.1

Labor Supply Elasticities for Workers with Different RTI over 3-Year-Intervals

Source: Authors' calculations based on SIAB 1985-2014, for West Germany.

Notes: The estimates are derived from the same specification as in Table 4. Further, a three-way interaction with three-year dummies is added to analyze the development over time, that is, $\log$ wages, RTI, and three-year dummies are interacted. The plotted lines correspond to the sum of the relevant coefficients for workers with mean RTI as well as workers with RTI one standard deviation below ("low RTI") and above ("high RTI") the mean. 


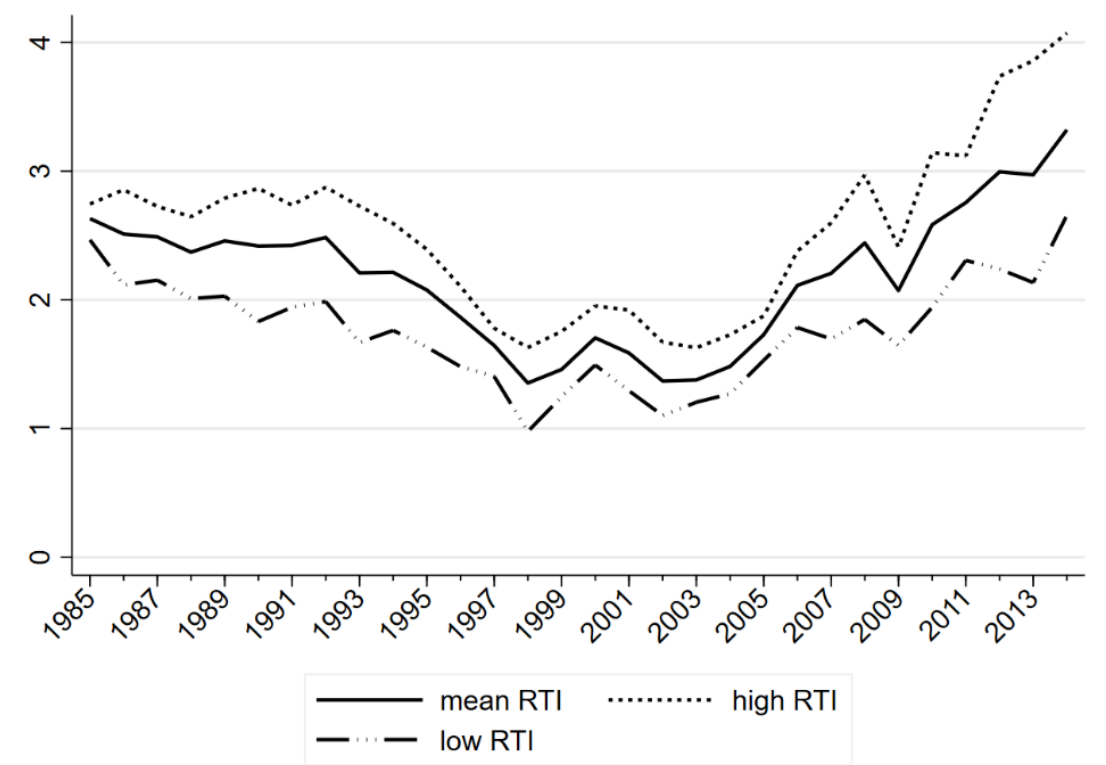

Figure A.2

Yearly Labor Supply Elasticities for Workers with Different RTI. Within-worker variation.

Source: Authors' calculations based on SIAB 1985-2014, for West Germany.

Notes: The estimates are derived from a stratified Cox model using the same control variables as in Table 4. Further, a three-way interaction with year dummies is added to analyze the development over time, that is, log wages, RTI, and year dummies are interacted. The plotted lines correspond to the sum of the relevant coefficients for workers with mean RTI as well as workers with RTI one standard deviation below ("low RTI") and above ("high RTI") the mean. 
${ }^{1}$ See Sokolova and Sørensen (2021) for a recent meta-analysis of studies on labor market monopsony. Section III describes the estimation approach in detail.

${ }^{2}$ The key assumption of the model is that wages are posted by firms, and workers decide on whether to accept or decline a wage offer. In line with this assumption, Brenzel, Gartner, and Schnabel (2014) showed that wage posting is the predominant mode of wage determination in Germany.

${ }^{3}$ As described in more detail in Section III, the hiring function of firms also plays a role.

${ }^{4}$ See the Online Appendix for a derivation of the equation.

${ }^{5}$ Note that in steady state, the share of hires from employment is equivalent to the share of separations to employment.

${ }^{6}$ We follow Manning $(2003,100-101)$ and assume that, conditional on $x$, the two types of separations are independent. Thus, one can estimate the separation rates separately. To estimate the elasticity of separations to non-employment, we use the whole sample (all jobs). We only use those jobs that do not end in non-employment when estimating the separation rate to employment.

${ }^{7}$ However, as a robustness check we also use exponential models in Appendix Table A.1. This increases the estimated elasticities as expected.

${ }^{8}$ Data access was provided via on-site use at the Research Data Centre (FDZ) of the German Federal Employment Agency (BA) at the Institute for Employment Research (IAB) and subsequently remote data access.

${ }^{9}$ Between 1979-99, the Federal Institute for Vocational Education and Training (BIBB) conducted the surveys in cooperation with the Institute for Employment Research (IAB). Since 2006 the BIBB cooperated with the Federal Institute for Occupational Safety and Health (BAuA) to administer the surveys.

${ }^{10}$ Using a finer occupational classification is not possible given the relatively small sample size of the BIBB data.

${ }^{11}$ In robustness checks, we include job spells with censored wages and impute the wages of these spells following the imputation procedure outlined in Dustmann, Ludsteck, and Schönberg (2009), Card, Heining, and Kline (2013) and Gartner (2005). More details are provided in the Online Appendix. This yields very similar results to our estimations excluding top-coded wages.

${ }^{12}$ We cannot fully focus on the voluntary supply-side driven separation behavior of workers because firings are still included in the data, as we cannot identify and distinguish firings from voluntary separations.

${ }^{13}$ We use imputed wages in Table B1 in the Online Appendix. All estimated labor supply elasticities are lower here, because of the addition of idiosyncratic variation to wages. The main results do not change.

${ }^{14}$ We do not decompose the routine-NRM difference, because the firm-level labor supply elasticities are similar in Table 2.

${ }^{15}$ The full set of regression coefficients for the estimations with RTI can be found in Table B3 in the Online Appendix.

${ }^{16}$ We use imputed wages in Table B2 in the Online Appendix. Specifically, we keep all censored wage spells instead of dropping them and apply the imputation procedure outlined in the Online Appendix to those spells. All estimated labor supply elasticities are lower here, because of the addition of idiosyncratic variation to wages. Furthermore, we use exponential models in Appendix Table A.1. As exponential models do not control for tenure, the estimated elasticities are higher (see Section III for more details).

${ }^{17}$ We thank two anonymous reviewers for the suggestions.

${ }^{18}$ To be complete, we include the base variables (log wages, RTI, year dummies), the three two-way interactions and the three-way interaction in the model. In deriving the labor supply elasticities shown in Figure 1, we take the sum of the appropriate coefficients.

${ }^{19}$ Theoretically, one could also observe no long-run trend in monopsony power if technological change did have a significant impact that was, however, counterbalanced by one or several other macro factors. However, we do not see an obvious suspect in this context and therefore regard this as an unlikely explanation.

${ }^{20}$ See Figure B.2 in the Online Appendix.

${ }^{21}$ Figure B.1 in the Online Appendix provides an additional robustness test by estimating the labor supply elasticities separately for 3-year-intervals. Thereby, all covariates - and not only RTI and log wages - may have 
time-variant effects on the separation probabilities. The main results are the same as in Appendix Figure A.1 and Figure 1.

${ }^{22}$ The stratified Cox model is a modification of the Cox model. The main difference between the estimators from the two models is that the stratified Cox model allows for the stratification of a predictor, that is, the stratified partial likelihood estimator conditions on the employment spells in the same stratum (worker). The stratified predictors in the stratified Cox model only need to satisfy the proportional hazard assumption for employment spells belonging to the same worker and therefore improve the identification argument in comparison to the Cox model (Kalbfleisch and Prentice, 2011).

${ }^{23}$ We estimate the wage elasticity of the share of recruits hired from employment $\epsilon_{\theta w}$ using the relation $\operatorname{Pr}\left[y_{i}=\right.$ $\left.1 \mid \mathrm{x}_{\mathrm{i}}, v_{m(i)}\right]=\Lambda\left(x_{i}^{\prime} \beta+v_{m(i)}\right)$, where $v_{m(i)}$ is a worker fixed effect. This estimator controls for worker fixed effects by conditioning on those workers who are hired from employment at one point in time and from non-employment at another and discarding those always hired from the same labor market status.

${ }^{24}$ These are the finance and insurance, public administration, and construction industry with coverage rates of 73-89 percent, 83-91 percent, and 67-83 percent in the years 1998-2014 (WSI 2018), respectively.

${ }^{25}$ These are the trade and repair, transport and communications as well as the catering and hotel industry with coverage rates of 37-65 percent, 38-61 percent, and 40-48 percent in the years 1998-2014 (WSI 2018), respectively.

${ }^{26}$ The industry variable indicates the economic activity as a 3-digit code and provides time-consistent information. We use the generated time-consistent industry codes in Eberle et al. (2011).

${ }^{27}$ In Tables B4, B5 and B6 in the Online Appendix we show the full estimation results of all the components of the labor supply elasticity for industries with different collective bargaining coverage by RTI, NRMTI and NRCTI respectively.

${ }^{28}$ The coefficients, standard errors and number of observations used for the estimations can be found in Table B7 in the Online Appendix. We use exponential models in Table 6, because by estimating the separation rate elasticities for different job tenure brackets, we already control for job tenure. Appendix Table A.1 shows our baseline results with exponential models without differentiating tenure brackets.

${ }^{29}$ The underlying reason is that tenure itself is determined by wages. See Section III for a detailed discussion.

${ }^{30}$ As the main advantage in using our TI measures lies in its continuous updating over time and the separate estimation by BIBB wave cancels this variation, we opt to focus on task groups here. Moreover, using task groups in this context facilitates the interpretation of the results. 